\title{
COOLING THE GREENHOUSE EFFECT:
}

Options and Costs for Reducing $\mathrm{CO}_{2}$ Emissions from the American Electric Power Company

\author{
Prepared by \\ Ned Helme, Executive Director \\ Mark G. Popovich, Senior Policy Analyst \\ Janet Gille, Public Affairs Coordinator

\section{Center for Clean Air Policy} \\ 444 North Capitol Street, Suite 602 \\ Washington, DC 20001 \\ (202) 624-7709
}

MAY 1993 


\section{DISCLAIMER}

This report was prepared as an account of work sponsored by an agency of the United States Government. Neither the United States Government nor any agency thereof, nor any of their employees, make any warranty, express or implied, or assumes any legal liability or responsibility for the accuracy, completeness, or usefulness of any information, apparatus, product, or process disclosed, or represents that its use would not infringe privately owned rights. Reference herein to any specific commercial product, process, or service by trade name, trademark, manufacturer, or otherwise does not necessarily constitute or imply its endorsement, recommendation, or favoring by the United States Government or any agency thereof. The views and opinions of authors expressed herein do not necessarily state or reflect those of the United States Government or any agency thereof. 


\section{DISCLAIMER}

Portions of this document may be illegible in electronic image products. Images are produced from the best available original document. 


\section{ACKNOWLEDGEMENTS}

This report was prepared under a project supported by funding from the U.S. Department of Energy and the U.S. Environmental Protection Agency, and under a subcontract administered by the National Renewable Energy Research Laboratory. Special thanks are owed to Bob San Martin and John Millhone (DOE), Bruce Schillo (EPA), and Blair Swezey (NREL) for their continued interest in and support of this effort. The Center's work has also benefitted from a generous grant of general support from the William \& Flora Hewlett Foundation.

A team of Center for Clean Air Policy staff contributed to this report. These include: Ned Helme, executive director; Mark G. Popovich, senior policy analyst; Janet-Ann Gille, public affairs coordinator; and Christine Denuel, assistant to the director. Chris Neme, R. Nicole Cordan, and Rick Piltz also built a solid base for this project during their tenure at the Center.

The assistance of many individuals was invaluable in bringing this project to a successful conclusion. Ira Shavel, Juanita Haydel, and Sikander Daryanani of ICF Resources, Inc. served as consultants for the computer modeling effort and shared their insights on a wide range of issues throughout the effort. Mark Levine and Jon Koomey at the Energy Policy Analysis Group, Lawrence Berkeley Laboratories helped spearhead the extensive analysis of energy conservation measures which played a major role in the outcome of this analysis. Finally, the members of the Center's Global Warming Policy Dialogue and Technical Advisory Group (Listed in Appendix G) generated invaluable comments during every step taken by the project. Without their help, this final report would not have been possible. It must be noted, however, that the statements and conclusions of this report are those of the Center alone and do not necessarily reflect the views of these many other consultants and reviewers. 


\section{CONTENTS}

EXECUTIVE SUMMARY

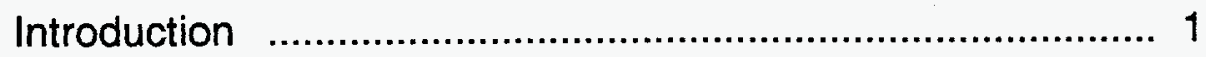

The Study $\quad$.......................................................................... 1

Policy Options $\quad$............................................................ 3

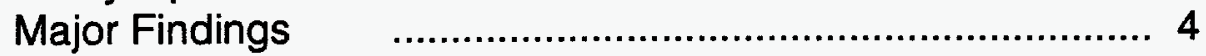

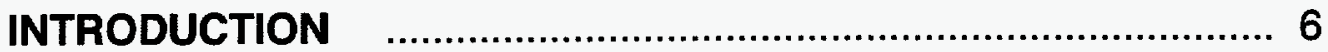

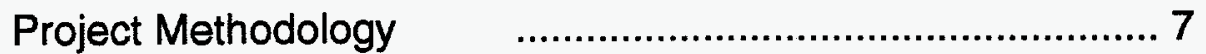

Structure of the Report …................................................ 8

$\mathrm{CO}_{2}$ Emissions Reduction Requirements $\quad$.................... 8

BASE AND POLICY CASES

MODELING RESULTS

Overall Results ............................................................ 13

Cost of Emission Reduction Measures and Annual

Compliance Costs ................................................... 16

Traditional Compliance Options: Effect on Generation

in 2015 Without Offsets Available .............................. 19

$\mathrm{CO}_{2}$ Emissions Reductions with Forest and Coalbed

Methane Offsets Available ....................................... 21

Meeting the Emission Reduction Requirement .................... 23

CONCLUSION

\section{APPENDICES}

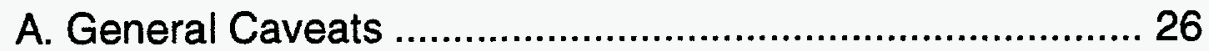

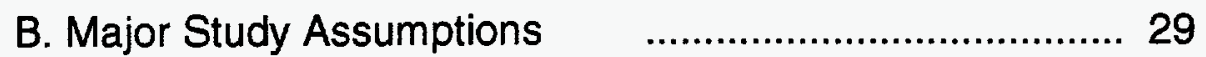

C. Background on the AEP System ………................... 36

D. Forest Offsets Alternatives ….................................. 37

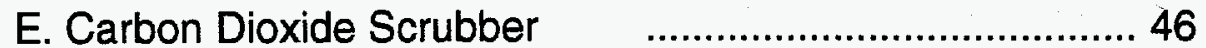

F. Data Sources ........................................................ 53

G. National Dialogue and Technical Advisory Group Members 


\section{LIST OF GRAPHS AND TABLES}

Graph 1

AEP Projected $\mathrm{CO}_{2}$ Emissions: 1989-2015

Graph 2

2015 Annual Compliance Costs

Graph 3 18

Graph 4 20

Traditional Compliance Options and New Technology with No Offsets: Generating Mix in 2015

Graph 5

Offsets Available: Generation Mix in 2015

Graph 6 23

Sources of $\mathrm{CO}_{2}$ Reductions: Selected Policy Case Results

Table 1 39

Potential Forestry Offsets in the AEP Region

Table 2 40

Sequestration Rates by Region, Land Type, and Treatment Measure for the AEP Region

Table 3

Land Rental Rates by Region, Land Type, and Treatment

Table 4 Crop Land Rental Rate Data

Table 5 42

Treatment Cost by Region, Land Type, and Treatment Measure

Table 6 43 Model Results in 2005 and 2015

Table 7 43

Total Forestry Offsets Available Under Constrained Offsets

Table 8 44 Aggressive Offsets Forestry Potential: Marginal Cost Distribution

Table 9 44 Aggressive Offsets: Model Results and Cost Curve

Table 10

Carbon Dioxide Collection, Transportation, and Disposal Methods Cost Estimates 


\section{EXECUTIVE SUMMARY}

\section{Introduction}

A recent report from the National Academy of Sciences concludes that the earth is likely to face a doubling of preindustrial greenhouse gases in the next half century. This doubling could be expected to push average global temperatures up from between 1.8 to 9 degrees Fahrenheit.

Much of the potential for human impacts on the global climate is linked to fossil fuel consumption. Carbon dioxide $\left(\mathrm{CO}_{2}\right)$ emissions from energy consumption in the U.S. totals about one-quarter of the world's total emissions from energy consumption.

Global warming is different from other environmental problems because $\mathrm{CO}_{2}$ emissions can be captured naturally by trees, grasses, soil, and other plants. In contrast, acid rain emissions reductions can only be accomplished through switching to lower-polluting fuels, conserving energy, or installing costly retrofit technologies.

The Earth's carbon cycle moves around 400 billion tons of carbon each year (1.5 trillion tons $\mathrm{CO}_{2}$ equivalent). Roughly 210 billion tons of carbon (770 million tons $\mathrm{CO}_{2}$ equivalent) annually cycle between the atmosphere and terrestrial biota. Since that is large compared to the roughly 26 billion tons of carbon generated annually by human activities, the potential role biotic systems might play in reducing the threat of global warming is the subject of ongoing consideration.

Terrestrial biota, such as trees, plants, grasses and soils, directly affect the $\mathrm{CO}_{2}$ concentrations in the atmosphere. A number of reports have concluded that forestry and land-use practices can increase $\mathrm{CO}_{2}$ sequestration and can help reduce or delay the threat of global warming.

\section{The Study}

The Center began this study in 1990 to generate detailed information to support effective policy decisions on global warming issues. This study analyzes the availability 
and cost of a wide range of supply-side, demand-side and emission offset measures to reduce $\mathrm{CO}_{2}$ emissions from the American Electric Power Company (AEP) -- one of the nation's largest investor-owned utilities. The study presumes a two-staged effort at cutting AEP's $\mathrm{CO}_{2}$ emissions. By 2005, emissions are reduced 10 percent below 1989 levels. In the second stage, $\mathrm{CO}_{2}$ emissions would be reduced 20 percent below 1989 levels by 2015 . While the results are specific to AEP, the study still yields detailed insights on the availability and costs of measures and their impacts on compliance costs and fuel mix.

In 1989, AEP emitted $106,000,000$ tons of $\mathrm{CO}_{2}$. This is about five percent of total U.S. utility $\mathrm{CO}_{2}$ emissions. If reductions in AEP's $\mathrm{CO}_{2}$ emissions are not required, the company's emissions would grow to $118,000,000$ tons in 2005 and up to $131,000,000$ tons in 2015. The 20 percent reduction requirement would require emissions to be cut by $46,000,000$ tons from the projected level of $131,000,000$ tons to $85,000,000$ tons in 2015.

To determine the least-cost option for AEP in meeting the 20 percent $\mathrm{CO}_{2}$ reduction, a variety of policy alternatives were provided. Under each policy case, a variable number of policy options are available to AEP, and a least-cost strategy is developed. In some policy cases only one or two options are available, in some cases all options are available. The only two constant options available are demand side management measures and non-nuclear supply technology (e.g. fossil fuels, renewable resources). Other options that are available, in some policy cases, are new nuclear units, $\mathrm{CO}_{2}$ scrubber technology and offsetting $\mathrm{CO}_{2}$ emissions through coalbed methane recovery and $\mathrm{CO}_{2}$ sequestration through forestry measures. This study does not offer a "point estimate" on the actual cost of each these options to AEP. Rather, it is a sensitivity analysis that develops estimates of the relative costs for a range of mitigation and offset measures. The results clearly demonstrate how allowing or restricting certain options can greatly affect a utility's cost of compliance.

Under a traditional scenario -- where compliance options such as fuel-switching, demand-side management (DSM), and newer supply-side technologies are available, but new nuclear plants, $\mathrm{CO}_{2}$ scrubbers, and offsets are not available -- the cost to AEP in reducing $\mathrm{CO}_{2}$ by 20 percent by 2015 is projected to be about 21 percent of operating revenue, or $\$ 1.65$ billion. Under a scenario that makes advanced supply-side alternatives (excluding new nuclear plants), energy conservation, and $\mathrm{CO}_{2}$ scrubbing technologies available to AEP, compliance cost declines to about 12 percent of operating revenue or $\$ 840$ million. The most flexible strategy, which allows for new supply technologies, energy conservation, and both forest offsets and coalbed methane recovery offsets, reduces that cost to about 2 percent of operating revenue or $\$ 170$ million. This is a ten-fold compliance cost savings for AEP under a flexible compliance policy. 


\section{Policy Options}

\begin{tabular}{|c|c|c|c|c|c|c|c|}
\hline 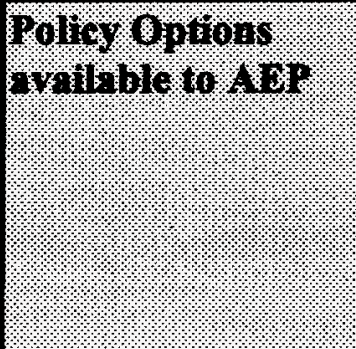 & Symang. & (1) & 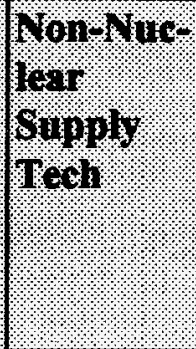 & 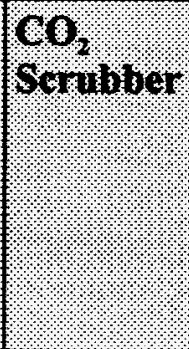 & Wheristion. & Worests: & 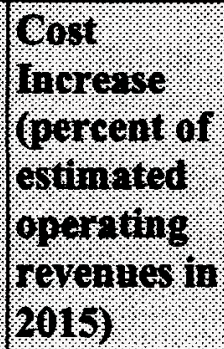 \\
\hline Base Case & $\begin{array}{l}\text { AEP project- } \\
\text { ed DSM up to } 2 \\
\text { cents } / \mathrm{kwh}\end{array}$ & $\begin{array}{l}\text { Conven- } \\
\text { tional }\end{array}$ & $\begin{array}{l}\text { Conven- } \\
\text { tional }\end{array}$ & None & None & None & N/A \\
\hline $\begin{array}{l}\text { Policy Case \#1 } \\
\text { New Nud/CO }{ }_{2} \text { Scrub/No } \\
\text { Offsets }\end{array}$ & Aggressive & $\begin{array}{l}\text { New } \\
\text { nuclear } \\
\text { allowed }\end{array}$ & Advanced & Available & None & None & 12 \\
\hline $\begin{array}{l}\text { Policy Case \#2 } \\
\text { No New Nuc/No Offsets }\end{array}$ & Aggressive & $\begin{array}{l}\text { No new } \\
\text { nuclear } \\
\text { units }\end{array}$ & Advanced & Available & None & None & 15 \\
\hline $\begin{array}{l}\text { Policy Case \#3 } \\
\text { No New Nuc/No Scrub/No } \\
\text { Offsets }\end{array}$ & Aggressive & $\begin{array}{l}\text { No new } \\
\text { nuclear } \\
\text { units }\end{array}$ & Advanced & None & None & None & 21 \\
\hline $\begin{array}{l}\text { Policy Case \#4 } \\
\text { Coalbed Methane/ } \\
\text { Constrained Trees }\end{array}$ & Aggressive & $\begin{array}{l}\text { New } \\
\text { nuclear } \\
\text { allowed }\end{array}$ & Advanced & Available & Available & $\begin{array}{l}\text { Constrain- } \\
\text { ed }\end{array}$ & 8 \\
\hline $\begin{array}{l}\text { Policy Case \#5 } \\
\text { Coalbed Methane/ } \\
\text { Aggressive Trees }\end{array}$ & Aggressive & $\begin{array}{l}\text { New } \\
\text { nuclear } \\
\text { allowed }\end{array}$ & Advanced & Available & Available & Expanded & 2 \\
\hline
\end{tabular}




\section{Major Findings}

While these numbers are specific to AEP, several key findings are useful to the policy debates over how to reduce the threat posed by increasing atmospheric concentrations of greenhouse gases:

- NATURAL OFFSETS, SUCH AS TREES, ofFER GREAT TRANSITIONAL STRATEGIES. The U.S. has extensive lands suitable for forest measures. In the short term, they are capable of offsetting large amounts of $\mathrm{CO}_{2}$ emissions. Forest offsets would buy time for a smoother transition toward use of less $\mathrm{CO}_{2}$ intensive fuels, further improvements in energy efficiency, or other alternatives.

- global WARMING POLICIES SHOULd ENSURE UTILITIES hAVE FLEXIBILITY IN MOLDING COMPLIANCE STRATEGIES. Flexibility to choose among supply-side, DSM, and offset alternatives dramatically reduces the potential cost of achieving $\mathrm{CO}_{2}$ emission reductions while still allowing utilities the latitude to make choices consistent with local concerns and conditions.

- THE FLEXIBILITY AVAILABLE TO UTILITIES IS DEPENDENT ON THE NATURE OF THEIR FUEL MIX. AEP'S dependence on coal yields it more options and flexibility. Coal-dependent companies will have higher baseline emissions of $\mathrm{CO}_{2}$. Gas-fired companies will have lower emissions -- and fewer alternatives to choose from for reducing them.

- THE MIX OF FUELS USED TO GENERATE ELECTRICITY IS SENSITIVE TO COST CHANGES AND POLICY CONDITIONS. With offsets available, AEP can delay making major changes in their fuel mix in the near term and still meet the emissions limit. Fuel mix will also be influenced by price, technology advances, and other factors over the next twenty-five years.

- tHE PRICE AND AVAILABILITY of NATURAL GAS SIGNIFICANTLY IMPACTS FUEL USE CHOICES. Natural gas-fired central station generating technologies release about one-half the $\mathrm{CO}_{2}$ released by coal-fired units, a real advantage in a global warming world. Both the cost of other alternatives and gas prices are likely to affect most directly the rate of growth in natural gas use.

- ENERGY CONSERVATION MEASURES ARE THE LEAST-COST OPTION AND CAN HELP SIGNIFICANTLY REDUCE $\mathrm{CO}_{2}$ EMISSIONS. Because AEP has not aggressively promoted energy conservation, there is extensive potential for cutting emissions by implementing cost-effective demand-side management (DSM) measures.

- OfFSETS, SUCH AS fOREST MEASURES AND COALBED METHANE RECOVERY, DRAMATICALLY REDUCE $\mathrm{CO}_{2}$ CONTROL COSTS. Trees, plants, soils, and other biota capture and hold carbon/carbon dioxide. Coalbed methane recovery ensures that an important greenhouse gas is not released into the 
atmosphere. These offsets can reduce $\mathrm{CO}_{2}$ levels at a much lower cost than other traditional methods of emission reduction. With these offsets, AEP could stabilize $\mathrm{CO}_{2}$ emissions at current levels through 2015 at relatively low costs.

- $\mathrm{CO}_{2}$ SCRUBBING AND UNDERGROUND DISPOSAL IS PART OF A LOWER-COST PACKAGE OF MEASURES FOR MEETING THE EMISSIONS LIMITS. $\mathrm{CO}_{2}$ scrubbing can be a cost-effective alternative. The relatively low-cost, innovative scrubbing technology included in the model and the availability of depleted natural gas wells and other formations suitable for $\mathrm{CO}_{2}$ disposal within the region are important factors. This low-cost option is dependent on site specific characteristics of AEP that are unlikely to be available to other utilities. Scrubbing technology and disposal options require further development.

- WITH OFfSETS AVAILABLE, REDUCTIONS IN $\mathrm{CO}_{2}$ EMISSIONS CAN BE ACHIEVED AT SIGNIFICANTLY LOWER COST THAN THROUGH MORE TRADITIONAL COMMAND-AND-CONTROL STRATEGIES. With offsets available, AEP can achieve a 20 percent reduction in $\mathrm{CO}_{2}$ emissions at one-tenth the cost of command-and-control strategies -- an average increase in customer electric bills of less than 2 percent. Compared to fuel-switching to natural gas or installing $\mathrm{CO}_{2}$ scrubbers, tree and methane recovery offsets, coupled with energy efficiency programs, offer the least-cost strategy for most utilities. 


\section{INTRODUCTION}

Human activity is altering the composition of the atmosphere and patterns of global climate. There is now widespread agreement in the scientific community that increasing concentrations of greenhouse gases will likely increase global average temperatures and alter weather patterns. A recently released report by the National Academy of Sciences concluded that the earth is likely to face a doubling of preindustrial greenhouse gases in the next fifty years. This doubling is projected to push up average global temperatures from 1.8 degrees to 9 degrees Fahrenheit. The higher reaches of this range would mean a climate warmer than at any point in human history.

International and U.S. policy makers have begun to act to reduce the threat of global warming. The United Nations Framework Convention on Climate Change, signed into force in June 1992, marks the initial step toward more concerted international cooperation and action. Under the treaty, participating nations are encouraged to stabilize their emissions at current levels by 2000 .

Even in advance of international action, the U.S. Administration had a "no regrets" policy toward climate change, supporting measures to reduce the atmospheric loading of greenhouse gases where it was economically justifiable -- but without considering any potential benefits from dampening the global warming threat. The Energy Policy Act of 1992 establishes a framework for companies to voluntarily register sources of greenhouse gas emissions and receive credit for voluntary early greenhouse gas reduction measures such as tree planting, coalbed methane recovery, fuel switching and energy conservation.

Over the last two years, the Center for Clean Air Policy (CCAP) examined the cost and availability of alternative strategies for reducing $\mathrm{CO}_{2}$ emissions from electric utilities. This study analyzes a range of supply-side, demand-side, and offset measures to cut $\mathrm{CO}_{2}$ emissions from one of the nation's largest investor-owned utilities, the American Electric Power Company (AEP), based on potential policy constraints.

The study presumes a two-staged effort at cutting AEP's $\mathrm{CO}_{2}$ emissions. By 2005 , emissions are reduced 10 percent below 1989 levels. By 2015, $\mathrm{CO}_{2}$ levels are cut to 20 percent below 1989 leveis. The study's reduction targets and timetable were set through the deliberations of the Center's Global Warming Policy Dialogue. (The 
Dialogue includes federal and state energy and environmental agencies, environmental and energy groups, utility and energy resource companies, academics, representatives from the national laboratory system, and others. The Dialogue membership is listed in Appendix G.) The 20 percent cut by 2015 is somewhat more stringent than the commitments to stabilize $\mathrm{CO}_{2}$ emissions at current levels made by many European and other industrialized nations during the international negotiations on a climate change treaty. However, the study's target is well below the 60 percent reduction in greenhouse gas emissions estimated by the International Panel on Climate Change (IPCC) as necessary to stabilize current atmospheric concentrations of gases believed to contribute to global warming.

The study results are very specific to AEP, the assumptions, and the policy conditions described. While generalizations of the results must be carefully drawn, an in-depth study of a single utility offers advantages. For example, it provides detailed insights on the availability and costs of measures and their impacts on compliance costs and fuel mix. This focus should contribute to a growing knowledge base that is being developed through national and regional analyses and through studies of individual sectors and companies.

Hundreds of assumptions and estimates were necessary to undertake this analysis. Ultimately, the study included the detailed computer modeling of nine distinct scenarios. Along with the base case, five of these generated the most significant insights. They are the focus of this report. The Base Case represents the "status quo" -- how AEP might operate in the absence of any requirement to curb $\mathrm{CO}_{2}$ emissions. The five policy cases test a range of assumptions about policy, technology, and economic variables. These iterative computer runs under varying conditions yield a sensitivity analysis that helps define the factors which may have the greatest impact on AEP's ability to meet this type of emissions limit in the most cost-effective manner. It is important to note that this study is not a point estimate study, offering actual costs of compliance under a $\mathrm{CO}_{2}$ reduction mandate. Instead it provides a sense of how costs of compliance can significantly change depending on the number of options that are available to utilities.

\section{PROIECT METHODOLOAY}

The analysis compares emissions, resource decisions, and costs under a $\mathrm{CO}_{2}$ emissions limit (all policy cases) with a base case projecting the same conditions but without an emissions restriction in force. This work was completed with the assistance of ICF Resources. ${ }^{1}$

1 The team of consultants from ICF Resources Inc. was headed by Ira Shavel and included Sikander Daryanani and Juanita Haydel. 
The emissions, costs, and other forecasted impacts were determined by using ICF's Integrated Planning Model (IPM). The IPM is a multiperiod, regional dispatch and capacity planning model well suited to studies of this nature. ${ }^{2}$ A dynamic system, the IPM is used to formulate least cost resource plans, fuel supply planning, and to project avoided costs. It is capable of developing environmental compliance strategies and can be used with explicit emissions limitations. ${ }^{3}$ Important model capacities include: integrated resource planning with all utility and non-utility supply and demand-side options; dynamic optimization over time, including a look-ahead feature; and an ability to evaluate emission compliance strategies. Perhaps most importantly, the system can model emission constraints while optimizing the mix of demand-side, supply-side, and offset options.

In a number of cases, supporting materials for the project were prepared by other consultants. Among the most significant of these were conservation supply curves, or DSM measures, for the residential, commercial, and industrial sectors. These were provided by the Energy Policy Analysis Group of Lawrence Berkeley Laboratory (LBL) (residential), University of Michigan and LBL (commercial) and Kenneth Anderson (industrial). (See Appendices $A, B$ and $G$ for information on the sources of study assumptions, the consultants, and their contributions.)

The Center, however, is responsible for all assumptions and estimates included in this analysis. In all cases, however, extensive review and prior approval was completed with outside experts before they were incorporated into the study. Two mechanisms were used to complete these reviews. First, assumptions and background papers prepared by the project team or the consultants were reviewed with the Center's Global Warming Technical Advisory Group (Appendix G). The Technical Advisors include representatives selected from the utility sector, energy resource businesses, environmental and energy groups, and state and federal officials. Second, they were also discussed in detail with the Center's Global Warming Policy Dialogue (Appendix G). As is the case in any modeling project, the forecasted impacts are critically dependent on the assumptions and estimates arrived at through these review and approval procedures. Both groups helped insure the balance and objectivity of the study. However, the Center, rather than ICF or any of the consultants, the Technical Advisory Group, or the Dialogue members, is solely responsible for the conduct of this analysis.

\footnotetext{
2 ICF Resources, Incorporated. "Overview of ICF's Integrated Planning Model".

Ibid. At least fifteen utility systems have been modeled using IPM. These include: American Electric Power; Arkansas Power \& Light; Carolina Power \& Light; Florida Power \& Light; Pacific Gas \& Electric; Pennsylvania, Jersey, Maryland Power Pool; New England Power Pool; New York Power Pool; Southern California Edison; Tennessee Valley Authority; Public Service of Indiana; Southem Company; Wisconsin Power \& Light; Salt River Project; and San Diego Gas \& Electric.
} 


\section{STRUCTURE OF THE REPORT}

The remainder of the paper is organized into two main sections. The main body of the report contains six sections. In turn, these will review:

* The $\mathrm{CO}_{2}$ reduction requirement applied in the modeling and the options available in the Base Case and five Policy Cases;

* An overview of results from the modeling, organized by the four main categories of mitigation measures -- supply-side measures, demand-side alternatives, $\mathrm{CO}_{2}$ scrubbing, and offsets;

* The costs associated with specific measures and the annual compliance costs in $\mathbf{2 0 1 5}$ for the Policy Cases;

* The effect on the mix of generating resources by fuel type under both the more traditional options (DSM, fuel switching, new generating technologies, renewables and $\mathrm{CO}_{2}$ scrubbing) and when the forest and coalbed methane offsets are available;

* The relative contribution alternative mitigation measures make toward compliance with the emission reduction requirements; and

* Final conclusions from the analysis.

More detailed information on the inputs to the modeling effort can be found in the appendices. These include:

- General caveats;

* The major assumptions incorporated into the study;

* Background on the existing AEP system; and

* The sources of data used to characterize major alternatives included in the study.

Because of the dramatic impact both forest offsets and $\mathrm{CO}_{2}$ scrubbing and disposal had on the study results, these are discussed in greater detail in the final two appendices.

\section{$\mathrm{CO}_{2}$ EMISSION REDUCTIONS REOUIREMENTS}

The analysis covers the period 1989-2015. The projected increase in AEP's $\mathrm{CO}_{2}$ emissions is related to both the increase in demand for electricity and the mix of fuels 
and generating technologies used to produce that power. Estimates of $\mathrm{CO}_{2}$ emissions fully considered these factors in assessing the likely growth in the company's emissions.

AEP's emissions are disproportionately high because of the company's dependence on coal-fired generating capacity. Coal plants produce nearly double the level of $\mathrm{CO}_{2}$ emissions associated with natural gas fired plants. As of 1989, the company relied on coal-fired units to supply 87 percent of its power needs, with only 8 percent derived from nuclear units, and about 5 percent from hydro, cogeneration and natural gas plants. (See Appendix $C$ for additional background information on the AEP system.)

According to the company's own estimates, the projected annual increase in electricity demand between 1989 and 2015 is 1.1 percent. This estimate was adopted for use in both the Base and Policy Cases. This growth projection is somewhat lower than past company forecasts. One additional change was made in forming the Base Case. Conservation measures (demand-side management (DSM)) costing two cents per Kwh or less was also credited to the Base Case. Since AEP's avoided cost is 2.2 cents per Kwh (the company's cost of producing power), these DSM efforts would cut AEP's production costs. This adjustment to the Base Case increases estimated compliance costs by allocating the benefits of inexpensive DSM investments to the Base Case, rather than the Policy Cases.

The emission limitation established by this study, requires AEP to cut $\mathrm{CO}_{2}$ emissions to 10 percent below 1989 levels by 2005 and by 20 percent in 2015. These requirements would entail substantial cuts in emissions. In 1989, AEP emitted 106,000,000 tons of $\mathrm{CO}_{2}$, or about five percent of total U.S. utility $\mathrm{CO}_{2}$ emissions. Without an emission reduction requirement, AEP's emissions would grow to $118,000,000$ tons in 2005 and up to $131,000,000$ tons in 2015 . The 20 percent reduction requirement would require that emissions be cut by $46,000,000$ tons from the projected level of $131,000,000$ tons to $85,000,000$ tons in 2015. (See Graph 1)

\section{GRAPH 1: AEP Projected CO2 Emissions}

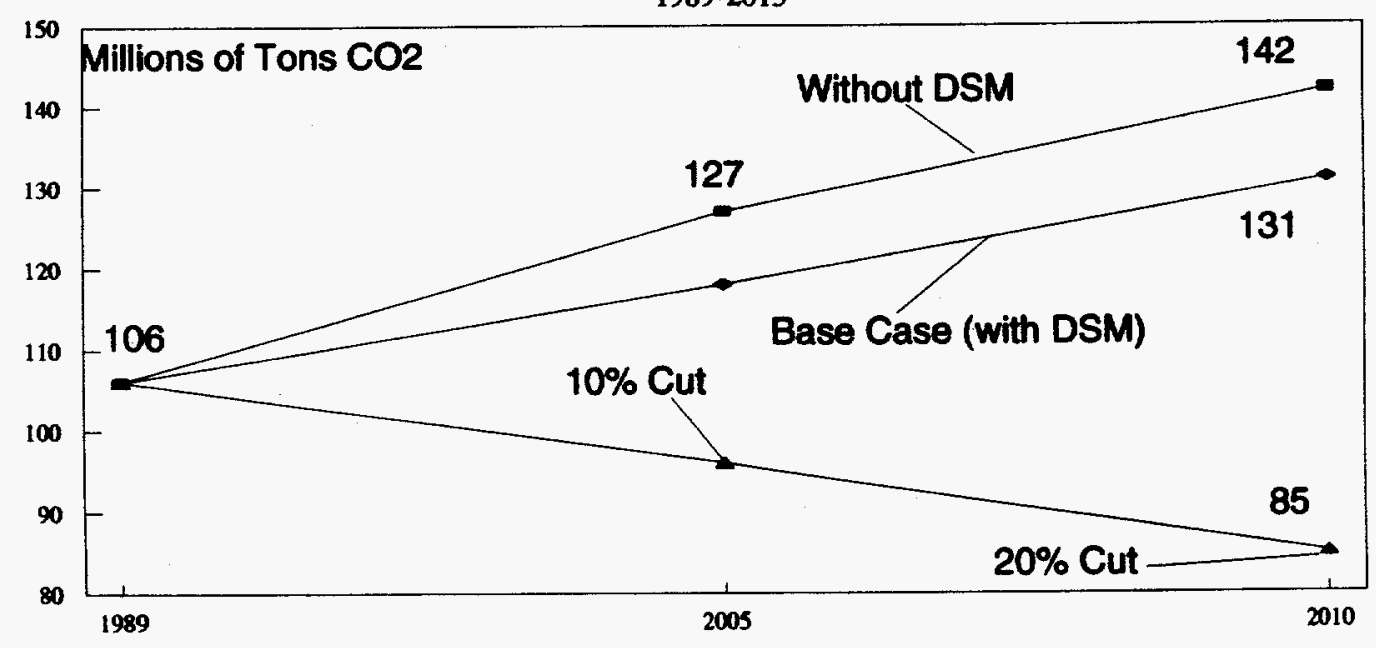




\section{BASE AND POLICY CASES}

The analysis evaluates the alternatives for and costs of cutting AEP's $\mathrm{CO}_{2}$ emissions. The requirements are for a 10 percent cut below 1989 levels by 2005 and for a 20 percent cut by 2015 . The analyses compare emissions, resource decisions, and costs under the $\mathrm{CO}_{2}$ limits imposed on all Policy Cases to these same factors under the Base Case, where no $\mathrm{CO}_{2}$ limits are in force.

The first three Policy Cases test the impact of $\mathrm{CO}_{2}$ scrubbing and limiting or allowing use of new nuclear power plants beyond those AEP already has in operation. The final two cases analyze an alternative approach which places extensive reliance on offsets, including both coalbed methane recovery and forest measures. In combination, these five scenarios provide a sense of how an array of measures might be assembled into a least-cost strategy for meeting the $\mathrm{CO}_{2}$ emissions limit.

\section{BASE CASE - $\mathrm{CO}_{2}$ LIMITS DO NOT APPLY}

BASE CASE w/DSM: Representing the status quo, this case illustrates how AEP might operate in the absence of $\mathrm{CO}_{2}$ emissions limits. Low cost demand-side management (DSM) measures (under two cents per kwh), were also included. Since these investments are clearly cost-effective for AEP, it was assumed that they should be part of this case. These measures reduce AEP's projected 2015 electrical generation forecast by 8 percent.

\section{POLICY CASES - $\mathrm{CO}_{2}$ LIMITS IN FORCE}

\footnotetext{
POLICY CASE \#1 - New Nuclear/ $\mathrm{CO}_{2}$ Scrubber/ No Offsets:

A range of demand-side, conventional and advanced supply-side options are available, including new nuclear-powered units (priced at $\$ 1,800$ per kW capital costs to reflect Electric Power Research Institute (EPRI) projections for the next generation of nuclear systems). A less traditional technology, $\mathrm{CO}_{2}$ scrubbing and disposal, can also be selected where cost-effective. Coalbed methane and forest offsets are excluded. Fuel switching is also available
} 


\section{POLICY CASE \#2 -- No New Nuclear/ No Offsets:}

This alternative is the same as the case above, except it is assumed that no new nuclear units are permitted. Once again, coalbed methane and forest offsets are unavailable.

\section{POLICY CASE \#3 -- No New Nuclear/ No $\mathrm{Co}_{2}$ Scrubber/ No Offsets:}

This run bars the use of $\mathrm{CO}_{2}$ scrubbers as well as new nuclear plants and offsets. It is the most restrictive of the policy cases. Fuel switching and demand-side management are available.

\section{POLICY CASE \#4 -- Coalbed Methane/ Constrained Trees Offsets:} Offsets, either through the sequestration of carbon dioxide or by reducing the release of other sources of greenhouse gases, cut emissions on a net basis. Forest offsets are available from tree planting and improved forest management in AEP's region. But, these offsets are constrained to 2.2 million available acres (See Appendix $B$ and $D$ ). Coalbed methane credits are from cost-effective recovery of methane otherwise released by the mining of coal in the AEP region. AEP's share of these offsets was based on their share of regional coal consumption, not on any specific estimate of potential reductions at AEP-owned mines. All other options described above are available.

\section{POLICY CASE \#5 --- Coalbed Methane/ Aggressive Trees Offsets:} In this case, the availability of forest offsets is significantly expanded to 5.3 million available acres, although availability is still restricted below the total potential estimated to be available by the U.S. Forest Service for the region. The quantity of coalbed methane credits available remains unchanged between the latter two cases, and all other options are available.

Two factors, which remain constant across the policy cases, are also important. Natural gas prices, for example, were assumed to reach $\$ 4.32$ in 2005 and $\$ 5.76$ in 2015 ( $\$ 1989$ Delivered Price). The estimated potential for energy conservation in the service territory was based on current technologies, which may undervalue the role DSM can play.

Key assumptions and estimates developed for use in the AEP global warming analysis include five sets of important variables:

* energy conservation -- estimates were developed for the residential, industrial and commercial sectors. 
* supply-side technologies -- both conventional and advanced technologies were considered for fossil-fueled, nuclear and renewable resource systems.

* forestry offsets -- both constrained and aggressive scenarios were characterized.

* coalbed methane offsets -- estimates of the cost-effective potential for recovering methane otherwise released by the mining of coal in the AEP region were made.

* carbon dioxide scrubbing and disposal -- the feasibility and cost of scrubbing $\mathrm{CO}_{2}$ from coal-fired units with disposal through underground injection was examined.

\section{MODELING RESULTS}

This section is divided into five components. The first summarizes the overall results of the modeling effort. The next reviews the annual costs in 2015 incurred to comply with the $\mathrm{CO}_{2}$ emissions limitation under all five policy cases. Next, the impact on AEP's generating mix of a set of three runs designed to test the effect of policies which would allow or restrict the use of new nuclear plants or $\mathrm{CO}_{2}$ scrubbers is gauged. The next package of scenarios also focuses on the company's generating mix and the impacts of alternative offset measures. In the final section, the relative contribution made by the various emission reduction measures are detailed.

\section{Section 1: Overall Results of The Modeling Exercise}

This section reviews some of the results from the modeling effort and is organized by categories of mitigation measures -- supply-side, demand-side, and offsets. Fossil-fueled and nuclear powered supply-side options were based on work by the 
Electric Power Research Institute and technical estimates developed in support of the National Energy Strategy by the U.S. Department of Energy. The availability and cost of wind power alternatives were derived from publications of the Pacific Northwest Laboratory, and biomass potential was based on publications from the Southeast Regional Biomass Energy Program. Demand-side alternatives were characterized by LBL (residential sector), University of Michigan and LBL (commercial sector), and by Kenneth Anderson (industrial sector). The potential for cost-effective recovery of methane released from coal mining was developed by the Center. The costs and impacts of forest offset measures are based on a report from the U.S. Forest Service. And finally, the $\mathrm{CO}_{2}$ scrubbing technology was characterized based on ongoing work at Argonne National Laboratory.

\section{SUPPLY-SIDE:}

- Coal-fired power plants play a predominant role in AEP's current generating mix. When offsets are available, coal generation in 2015 is slightly higher than in 1989 . When only traditional compliance options -fuel-switching and DSM -- and $\mathrm{CO}_{2}$ scrubbing are available, the role of coal-fueled power plants declines 13 percent -- from 103,000,000 GWH in 1989 to about $90,000,000 \mathrm{GWH}$ in 2015 . Under a totally traditional scenario -- fuel-switching, DSM, renewables and present-technology nuclear are the only options available $\left(\mathrm{CO}_{2}\right.$ scrubbing is not available)-coal-fueled mix drops to $70,000,000 \mathrm{GWH}$ in 2015 (-45\% compared to the Base Case).

- Advanced supply-side technologies -- those fired by coal and others dependent on natural gas, nuclear or other energy sources -- did not significantly penetrate into AEP's generating capacity nor did they contribute to meeting the emissions limit. In part, this reflects AEP's current excess capacity. However, the analysis also showed that the costs of these options were higher than demand-side and offset alternatives.

- The Policy Cases suggest that reliance on natural gas use for generating electricity could be very sensitive to price and policy conditions. When offsets, $\mathrm{CO}_{2}$ scrubbing, and/or new nuclear plants are available, natural gas use is limited. Where these options are not available, gas increases from negligible levels in 1989 to as much as 23 percent of the generating mix by 2015 . The costs of gas and its close competitors are key.

- Nuclear power plays the greatest role where new nuclear plants are available and when neither $\mathrm{CO}_{2}$ scrubbers nor offsets are allowed. These projections are based on advanced nuclear technologies with 80 percent capacity factors and estimated capital costs of $\$ 1,800$ per $\mathrm{kW}$. In this case, nuclear generation triples and its share in the generating mix 
expands to just less than 20 percent in 2015. Nuclear power displaces natural gas and renewables. Both nuclear's capital costs and the capacity factor are key.

- Renewables, such as biomass and wind, do not currently play a significant role in the AEP system. When new nuclear plants, $\mathrm{CO}_{2}$ scrubbing, and offsets are not available, the contribution of renewables is almost three times the 1989 level. However, this still accounts for only 3 percent of total generation, and renewable energy technologies are able to increase their role in the generating mix only in the two most restricted cases where more expensive emission reduction options are selected. Wind energy potential in the AEP region is concentrated in the six month Fall-Winter period and would require development of sites with lower average wind speeds and the application of more advanced technologies than are currently in use. Based on an assessment of biomass potential completed by the Southeastern Regional Biomass Energy Program, just over twelve million tons of annual energy wood from logging residues, cull trees, and surplus growth might be available in specific regions within Kentucky, Virginia, and West Virginia. This biomass potential has been largely untapped because of low Qualifying Facility rates set by utility regulatory commissions in the region and low prices for more traditional fossil fuel resources.

\section{DEMAND-SIDE:}

- DSM contributes to both emissions reduction and the generation mix in all policy cases. It reduces total generation requirements by about 20 percent, providing $18,000,000$ tons toward the emission reduction target. DSM is the least-cost source of emissions reductions, with the exception of some of the very low cost forest offsets and for offsets achieved through coalbed methane recovery. To a very limited extent, the least-cost forest offset measures displace some higher cost investments in DSM in the Policy Case with the most aggressive offset conditions. In the Base Case, DSM reduces electric power demand by over 13,000 GWH. In Policy Cases which only allow for the use of traditional compliance options, this increases to as much as $32,000 \mathrm{Gwh}$.

\section{$\mathrm{CO}_{2}$ SCRUBBER:}

- $\mathrm{CO}_{2}$ scrubbers provided about $11,000,000$ tons of reductions when this option was selected. However, it did prove to be more expensive than some alternative measures. Scrubbers reduce power output from affected plants, and usually entail a capacity penalty. However, because of AEP's 
excess capacity, the scrubbing option was not burdened by the cost of new replacement capacity. Disposal capacity and costs are also crucial to $\mathrm{CO}_{2}$ scrubbing. The availability of depleted natural gas wells and similar formations in the AEP region provides a disposal alternative that would not be available in many other parts of the country.

\section{OFFSETS:}

- Approximately 2,800,000 tons of Coalbed Methane Offsets were projected to be available annually through 2005 and 2015 . This was based on estimates of the recoverable gas from coal mining operations in the region -- not specifically from AEP mines. The credits available to AEP were set as the company's share of coal use in the region. These offsets are available at no cost to AEP -- only cost-effective measures (cost are equal to or less than the price or value received) are included. It was also assumed that mine owners would bundle credits and transfer them to utility coal customers in order to maintain sales. As such, coalbed methane offsets were selected whenever they were available.

- Forestry Offsets play a significant role. In 2015 under the aggressive tree offset scenario, the model selects $3,300,000$ acres of forest planting and management measures capable of sequestering $28,200,000$ tons of $\mathrm{CO}_{2}$. While large, this accounts for just over half (60 percent) of the total forest offsets projected to be available by the U.S. Forest Service for the AEP service territory.

\section{Section 2: Cost of CO, Emission Reduction Measures And Annual Compliance Costs In 2015}

The estimated costs of compliance with the $\mathrm{CO}_{2}$ emission reduction requirement derived by this study are relatively low. In the most traditional (and highest cost) approach, compliance is achieved at an average cost of $\$ 36$ per ton of $\mathrm{CO}_{2}$. In the most aggressive offsets case, these costs are reduced dramatically to about $\$ 3.70$ per ton of $\mathrm{CO}_{2}$. Some other analyses have predicted that costs of over $\$ 33$ per ton of $\mathrm{CO}_{2}$ would be necessary simply to stabilize U.S. $\mathrm{CO}_{2}$ emissions at 1990 levels by the turn of the century. However, even these figures obscure the low costs associated with some specific mitigation measures. For example, significant reductions can be achieved through coalbed methane recovery, DSM (below \$40/Mwh), and forest offset measures. As Graph 3 illustrates, the costs for these measures range from no net cost for coalbed methane recovery and the lowest cost DSM, to $\$ 4-\$ 8$ per ton of $\mathrm{CO}_{2}$ under the forest offset measures, and up to a maximum of $\$ 27$ per ton of $\mathrm{CO}_{2}$ for DSM at \$40/Mwh. 
Annual AEP compliance costs in 2015 (See Graph 2) vary from a high of $\$ 1.6$ billion (20 percent of estimated AEP revenues) in 2015 to as little as $\$ 170$ million (2 percent of estimated operating revenues) when energy conservation and forest and coalbed methane offsets combine for the least-cost Policy Case. This ten-fold difference in costs highlights the importance of policy choices that would provide flexibility and reward innovation in forming and implementing measures to cut $\mathrm{CO}_{2}$ emissions.

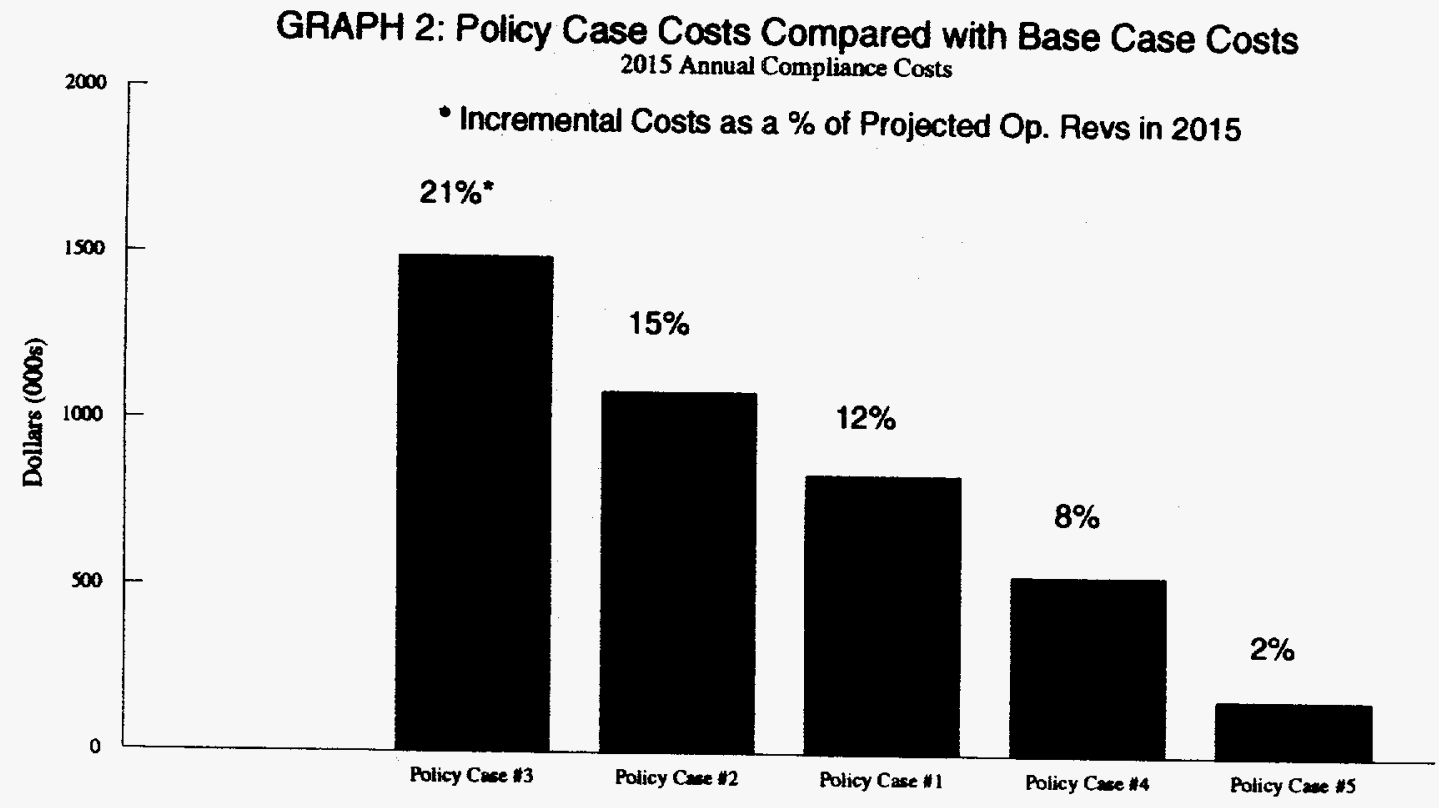

Annual compliance costs for each Policy Case are reviewed below. They represent the difference between total costs under the Base Case and in each Policy Case in 2015. 
口 POLICY CASE \#2 - No New Nuclear/ No Offsets:

Where new nuclear plants and offsets are not allowed but $\mathrm{CO}_{2}$ scrubbing

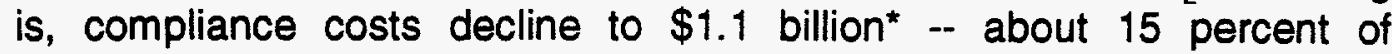
estimated operating revenues in 2015.

POLICY CASE \#1 - New Nuclear/ $\mathrm{CO}_{2}$ Scrubber/ No Offsets:

Allowing new nuclear plants reduces annual compliance costs. The $\mathrm{CO}_{2}$

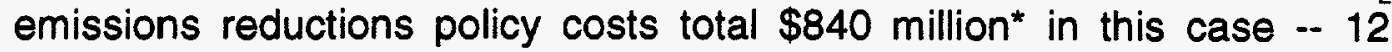
percent of estimated operating revenues in 2015.

- POLICY CASE \#4 --- Coalbed Methane/ Constrained Trees: Even when constrained, coalbed methane and forestry offsets dramatically reduce compliance costs. In this case, the cost of meeting the reduction goal is $\$ 537$ million $^{*}$-- 8 percent of estimated operating revenues in 2015.

- POLICY CASE \#5 --- Coalbed Methane/ Aggressive Trees:

This was the least-cost scenario identified by the analysis. When more aggressive forestry offsets are combined with coalbed methane credits, 2015 compliance costs are further reduced to $\$ 170$ million* -- 2 percent of estimated operating revenues in 2015.

\section{GRAPH 3: Estimated CO2 Reduction Costs for AEP}

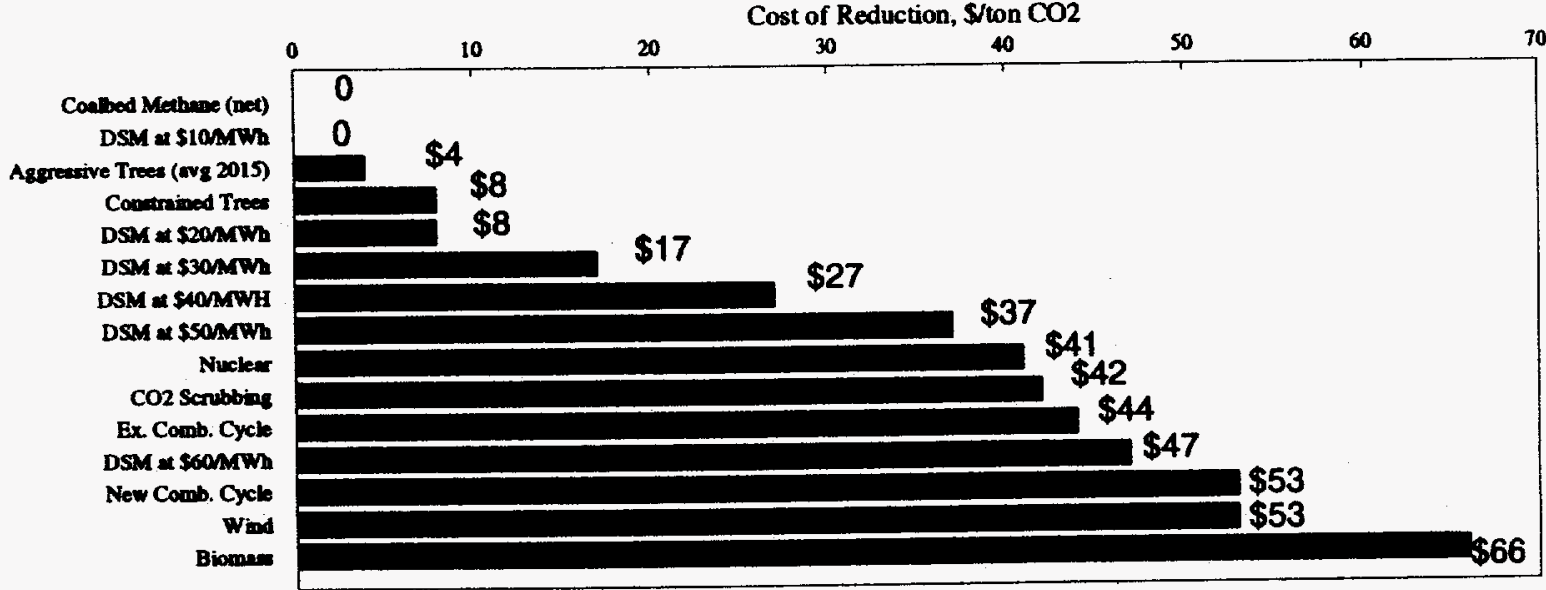




\section{Section 3: Iradifional Compliance Options -- Effect on Generation Mix in 2015 Without Offsets Available}

The following summarizes modeling results from the first three scenarios which do not allow for the use of Offsets in reducing $\mathrm{CO}_{2}$.

- POLICY CASE \#1 -- New Nuclear/ $\mathrm{CO}_{2}$ Scrubber/ No Offsets:

This case indicates the impact new nuclear plants and $\mathrm{CO}_{2}$ scrubbing would have on the generating mix when offsets are not available.

- POLICY CASE \#2 - No New Nuclear/ No Offsets:

$\mathrm{CO}_{2}$ scrubbers are available, but no new nuclear units are permitted. And once again, coalbed methane and forest offsets are unavailable. This leads to greater reliance on the scrubbing option and low $\mathrm{CO}_{2}$ emitting (natural gas) and non-emitting (renewable resources) supply options.

POLICY CASE \#3 --- No New Nuclear/ No $\mathrm{CO}_{2}$ Scrubber/ No Offsets:

Neither $\mathrm{CO}_{2}$ scrubbers, new nuclear plants, nor offsets are available. With many of the lower cost compliance options precluded, maximum reliance is placed on natural gas and renewables supply alternatives.

\section{Results:}

- All Three Cases:

DSM contributes to both emission reductions and change in the generation mix, reducing total generation requirements by about 20 percent (about 31,000 Gwh). These measures provide about 18,000,000 tons toward the $\mathrm{CO}_{2}$ emissions reduction requirements.

- New Nuclear/ $\mathrm{Co}_{2}$ Scrubber/ No Offsets:

Where new nuclear plants and $\mathrm{CO}_{2}$ scrubbing are allowed, coal generation continues to contribute substantially to the mix. The total power generated from coal-fired units, however, declines from 103,000 $\mathrm{gWh}$ in 1989 to $93,000 \mathrm{gWh}$ in 2015. This is 60 percent of the mix in the policy case in 2015. Nuclear powered capacity is added, tripling over 1989 levels (from $9,485 \mathrm{gWh}$ in 1989 to $30,500 \mathrm{gWh}$ in 2015). With this change, nuclear accounts for just less than 20 percent of the mix in 2015. Natural gas $(1,900 \mathrm{gWh})$ and renewables $(1,100 \mathrm{gWh})$ remain stable when 1989 and 2015 levels are compared. 
- New Nuclear/ $\mathrm{CO}_{2}$ Scrubber/ No Offsets And No New Nuclear/ No Offsets:

Emissions reductions are obtained through $\mathrm{CO}_{2}$ scrubbing in both these cases. In 2015, scrubbing of AEP's Gavin Plant provides over 12,000,000 tons of reductions.

- No New Nuclear/ No Offsets And No New Nuclear/ No Co Scrubber/No Offsets:

When new nuclear plants are unavailable, natural gas plays an expanded role. The generating mix changes dramatically. Coal drops to 86,000 gWh (-20 percent from 1989 levels), and natural gas increases to 19,900 gWh (12.7 percent of the mix) in 2015. The penetration of renewables quadruple above 1989 levels to $4,900 \mathrm{Gwh}$ or 3 percent of the mix. DSM remains at about 20 percent of the mix.

- No New Nuclear/ No Co 2 Scrubbers/No Offsets:

Where neither new nuclear plants, $\mathrm{CO}_{2}$ scrubbers, nor offsets are available, the decline in coal use and the increase in natural gas consumption are the greatest. Coal declines from about $103,000 \mathrm{gWh}$ in 1989 to about $70,000 \mathrm{gWh}$ in 2015 . Natural gas, however, rises sharply to 23 percent of the mix, increasing from negligible amounts in 1989 to over $36,000 \mathrm{gWh}$ in 2015 . Both renewables and DSM remain unchanged here as compared to cases where new nuclear capacity is not allowed.

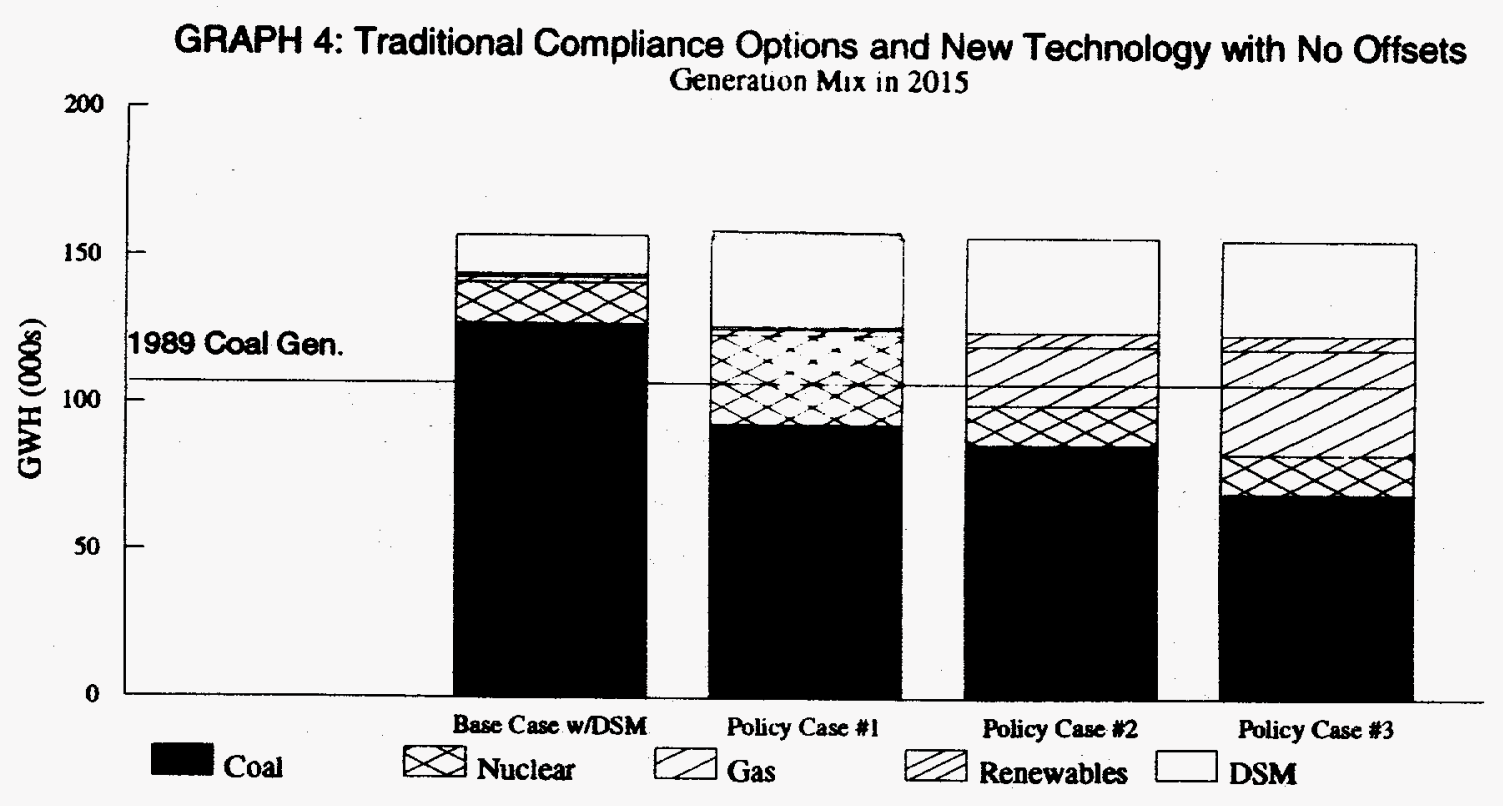




\section{Section 4: $\mathrm{CO}_{2}$ Emissions Reductions With Forest and Coalbed Methane Recovery Offsets Available-- Effect on Generation Mix in 2015}

The next three Policy Cases provide insights on the availability of two relatively low-cost offset options -- forest measures and recovery of coalbed methane -- would have on the generating mix. These include:

- POLICY CASE \#1 -- New Nuclear/ $\mathrm{CO}_{2}$ Scrubber/ No Offsets:

This scenario, included in the first set of runs, is provided again to facilitate comparison. Coal use was highest, gas consumptions was lowest, and nuclear power was expanded under this option in the projections for 2015.

- POLICY CASE \#4 -- Coalbed Methane Recovery/ Constrained Trees Offsets:

Forest offsets are available from tree planting and forest management in AEP's region. Neither forest offsets available in other U.S. regions or internationally -- which are likely to have lower costs -- were considered. The availability of forest offsets in the AEP region are further constrained through acreage enrollment limits and a required 2:1 offset ratio. Coalbed methane includes AEP's share of offset credits generated from the cost-effective recovery of methane released by the mining of coal in the AEP region, rather than those mines specifically supplying the company. This is equal to $2,800,000$ tons of $\mathrm{CO}_{2}$ offsets. The coalbed methane recovery offsets remain unchanged between this case and the next scenario.

- POLICY CASE \#5 -- Coalbed Methane Recovery/ Aggressive Trees Offsets:

The availability of forest offsets is expanded by easing enrollment limits and dropping the 2:1 offset requirement. As a result, $28,200,000$ tons of $\mathrm{CO}_{2}$-equivalent forest offsets are selected in 2015. The most expensive measures selected had a cost of under \$10/ton.

\section{Results:}

- Coalbed Methane/Constrained Trees:

Where the forest offsets are limited, 6,500,000 tons of forestry offsets are selected in 2015. While coal drops from 87 percent of the mix in 1989, it maintains about a two-thirds ( 66 percent) share of the generating mix under this 
case. In fact, coal-fired generation actually equals 1989 levels. Coal use is slightly higher than in the case where offsets aren't available but new nuclear plants and $\mathrm{CO}_{2}$ scrubbers are. But coal-fired generation is about one-third higher in the Base Case -- with no $\mathrm{CO}_{2}$ limits in place. Nuclear power grows somewhat to provide 14 percent of the mix. Natural gas use is negligible and renewables remain constant. DSM continues to provide the equivalent of 20 percent of the total mix.

- Coalbed Methane/Aggressive Trees:

When more aggressive forest offsets are available, 28.2 million tons of offsets are selected in 2015. Three-quarters of these forest offsets are available at costs of under $\$ 10$ per ton of $\mathrm{CO}_{2}$. The AEP generation mix is significantly affected. Coal provides almost 73 percent of the mix, $113,500 \mathrm{gWh}$ in 2015 compared to $103,000 \mathrm{gWh}$ in 1989 . Nuclear provides $13,900 \mathrm{gWh}$, and renewables are unchanged at $1,100 \mathrm{gWh}$. DSM, at 28,500 gWh, provides about 18 percent of the mix.

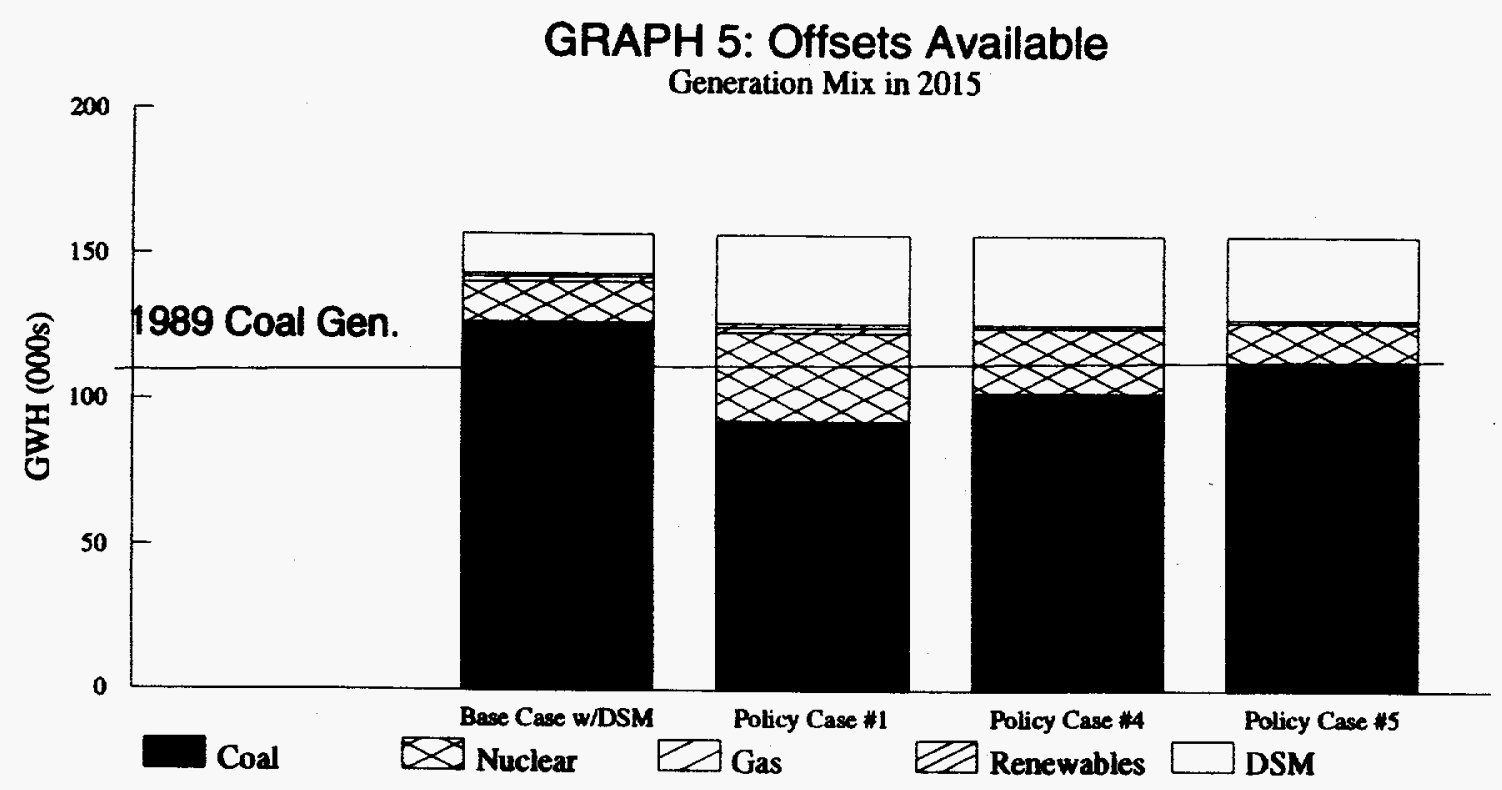




\section{Section 5: Meeting The $\mathrm{Co}_{2}$ Emissions Reduction Requirement:}

Graph 6 illustrates the role played by the main supply-side, demand-side, and offset options in reducing AEP's carbon dioxide emissions and in meeting the emissions cap. The three scenarios include: Policy Case \#2 --No New Nuclear/ No Offsets - which places greater reliance on coal to gas switches and on the $\mathrm{CO}_{2}$ scrubber on the Gavin

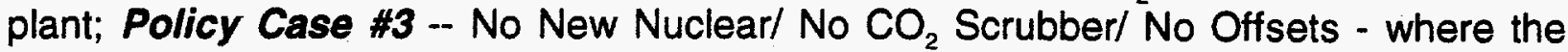
lack of other options leads to very large increases in natural gas use; and Policy Case \#5 -- Coalbed Methane/ Aggressive Trees - where less expensive offset alternatives dramatically shift AEP's compliance strategy.

AEP's projected growth rate of about 1.1 percent per year through 2015 was incorporated into this analysis and significantly influences projected $\mathrm{CO}_{2}$ emissions from the company. Under the Base Case, emissions rise sharply from 106,000,000 tons in 1989 to $118,000,000$ tons in 2005, and to $131,000,000$ tons in 2015. The $\mathrm{CO}_{2}$ emissions reduction requirement limits these releases to no more than $96,000,000$ tons in 2005 (10 percent below 1989 levels) and 85,000,000 tons in 2015. This is a 46,000,000 ton (-35 percent) cut from Base Case emissions in 2015.

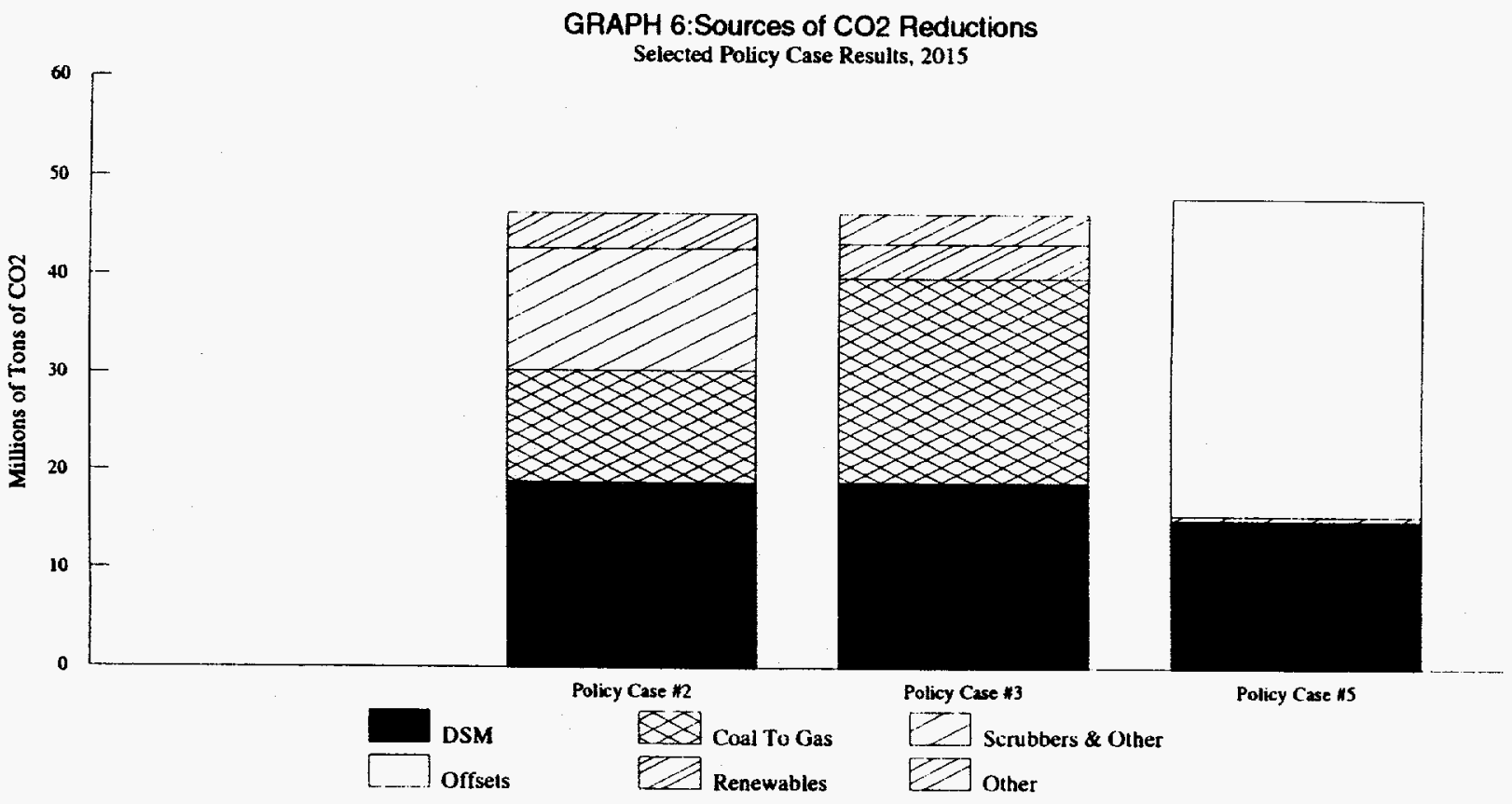


- In All Three Cases:

DSM plays a crucial and relatively stable role in cutting AEP's $\mathrm{CO}_{2}$ emissions. DSM accounts for about thirty percent of the reductions in all three cases -- from $15,000,000$ tons to $18,800,000$ tons of $\mathrm{CO}_{2}$ reductions.

- No New Nuclear/ No Offsets:

In addition to DSM, the most cost-effective options for cutting carbon dioxide were a switch from coal to natural gas powered generation $\left(11,500,000\right.$ tons) and maximum use of the $\mathrm{CO}_{2}$ scrubber and disposal system modeled for the two 1,300 MW units at the Gavin facility $(12,500,000$ tons $)$.

- No New Nuclear/ No Co 2 Scrub/No Offsets:

While DSM continues as a major source of emissions reductions $(18,800,000$ tons), the limitation on supply options and other means for cutting emissions leads to large increases in natural gas use. As such, coal to gas fuel switching contributes to a $21,000,000$ ton cut in $\mathrm{CO}_{2}$ emissions in 2015.

- Offsets Prohibited:

In both New Nuclear/No Offsets and in No New Nuclear/No $\mathrm{CO}_{2}$ Scrubber/No Offsets, the lion's share of emissions reductions is derived from fuel switching from coal to gas (ranging from $11,500,000$ to $21,000,000$ tons of reductions) and, where it is available, $12,500,000$ tons in cuts from the $\mathrm{CO}_{2}$ scrubber. A much smaller reduction is also due to the selection of renewable resources $(3,500,000$ tons).

- Coalbed Methane/ Aggressive Trees:

As constraints on offset alternatives are reduced, fuel mix changes decline sharply, with offsets and DSM capable of filling the need for reductions. DSM declines from $18,800,000$ tons in the first two cases to $15,000,000$ tons. Trees and coalbed methane recovery combine to cut emissions by $32,500,000$ tons per year in 2015. Coalbed methane provides about $2,800,000$ tons of the total reduction in $\mathrm{CO}_{2}$ attributed to offsets where it is available. 


\section{CONCLUSION}

This study offers two very significant conclusions: (1) Flexibility will be a key component of any legislative or regulatory efforts to significantly reduce $\mathrm{CO}_{2}$ levels while minimizing the costs of compliance; and (2) Offsets -- both forest and coalbed methane recovery -- when coupled with energy efficiency, offer the greatest opportunity for meeting $\mathrm{CO}_{2}$ reduction levels in a least-cost way.

Recent activities on the national and international level herald initial movement from debate over the potential threat posed by increasing atmospheric concentrations of greenhouse gases toward development of mitigations measures. Both the International Convention on Climate Change and provisions in the 1992 U.S. Energy Policy Act acknowledge the role that forestry offsets may play in addressing the threat of global climate change. Preliminary results of this study were presented to both international delegates and the U.S. representatives during the U.N.-sponsored negotiations which culminated in the Rio Treaty, and to members of Congress during debates on language included in the new energy law to encourage voluntary efforts to reduce greenhouse gas emissions. Policy action, both in the U.S. and internationally, should prompt redoubled attention toward addressing the many practical implementation issues that will confront forestry offset and other innovative mitigation proposals.

Some U.S. utility companies are already actively investigating the role DSM and forest offsets investments could play in addressing greenhouse gas emissions. More and more utilities are announcing plans to initiate specific forest offset, energy conservation, fuel switching, or other programs. There is much to be learned from their experiences -- both successes and failures -- over the next few years.

The programs that utilities and others have begun will provide the necessary information to define the potential these alternatives present as part of a transitional global warming mitigation strategy. The Center will continue its work in this area and to advocate for the development of flexible approaches to $\mathrm{CO}_{2}$ reduction that meet environmental goals in a least-cost manner. 


\section{Appendix A}

\section{GENERAL CAVEATS}

Continued scientific uncertainty over the more precise relationship between global emissions of greenhouse gases and the likely impact on climate is the most important caveat to the study. There is no policy consensus on what level of emissions reductions target may be needed. The scientists on the IPCC concluded that as much as a 60 percent cut from current levels may be needed. The 20 percent goal for 2015 reflects the recommendation of the 1st Annual Conference on Climate Change held in Montreal in 1988. Several European nations have committed to reductions in this range to be achieved by $2005-2010$.

- Because of its overwhelming dependence on coal and its limited commitment to DSM, AEP would initially appear to be a "worst case" utility for studying $\mathrm{CO}_{2}$ emissions reductions. Results show, however, that a utility with a $\mathrm{CO}_{2}$-intensive fuel $\mathrm{mix}$ and untapped potential for conservation may be better positioned compared to other utilities if a percentage emissions reduction target is applied.

Study results are very specific to AEP and the assumptions and policy conditions imposed.

Greater reductions in power demand and $\mathrm{CO}_{2}$ emissions were selected from among the DSM measures available under the Policy Cases. Some of this DSM would be cost-effective without a $\mathrm{CO}_{2}$ emissions limitation (up to an average cost of about $\$ 0.025$ per $\mathrm{kWh}$ ). To the extent that AEP would pursue these measures under Base Case conditions, compliance costs are understated. To the extent AEP would not capture these benefits under Base Conditions, this allocation tends to overstate compliance costs. Further, DSM estimates depend critically on implementation, and public and industry acceptance. Penetration rates for DSM are also controversial. However, DSM estimates were based on current technologies -- which would tend to overstate compliance costs and understate technical potential.

Cogeneration was also included as an option. The potential for cogeneration is large. Nationally, the Gas Research Institute (GRI) projected that cogeneration in the industrial and commercial sector would grow from about $26.8 \mathrm{Gw}$ in 1989 to almost $64 \mathrm{Gw}$ in 2010. However, estimating the cogeneration potential in the AEP region over the study time period is difficult. Two factors suggest the rate of growth in AEP's service territory would be lower than the national average. First, national 
projections are dependent on the introduction and widespread adoption of both new cogeneration and space cooling technologies. Second, commercial and industrial electric rates in the AEP region are well below national average. Low electric prices would tend to dampen growth in cogeneration. As such, the model assumed a cogeneration cap of 6 percent of total demand.

The study's assumptions on $\mathrm{CO}_{2}$ scrubbers are based on development work underway at Argonne National Laboratory. This technology has been tested at commercial scale, but is considered unproven. The disposal method used -- injection into depleted gas wells and other underground formations--is illustrative, but should be considered untried. Based on current work, capital costs of about $\$ 265$ per $\mathrm{kW}$, and $\$ 12$ per $\mathrm{MWh}$ for disposal costs are used. This represents relatively low $\mathrm{CO}_{2}$ scrubbing costs. But while the $\mathrm{CO}_{2} / \mathrm{O}_{2}$ process would also remove $\mathrm{SO}_{2}$ and $\mathrm{NO}_{\mathrm{x}}$, this benefit was not included. $\mathrm{CO}_{2}$ scrubbers, in light of the importance of an available and affordable disposal alternative, may only be an option for utilities in gas producing regions or with access to underground salt domes, and similar structures. (See Appendix E.)

The estimated cost and availability of forest offsets in the AEP region are based on work completed by the U.S. Forest Service. The estimates of the availability of forest offsets used here, however, are more conservative. (See Appendix D.)

New generating technologies assumptions are highly uncertain and depend on technological progress, R\&D funding, government policies, and the costs of fuels. However, even with the lower costs and higher capacity factors of many advanced supply technologies, they were not an important factor in this study.

Natural gas price estimates implicitly considered some of the price increases that might be induced by increased demand for natural gas resulting from $\mathrm{CO}_{2}$ emissions limits. However, it is uncertain the estimates fully capture this effect.

Coal price estimates did not include price declines that might be expected from reduced demand under a $\mathrm{CO}_{2}$ reduction policy.

* The cost and performance of renewable options are generally more uncertain than the more conventional supply-side options. In some cases, these technologies are not mature and proven.

Macroeconomic effects that would reduce electric power demand were not modeled. Customer response to increased prices under a carbon 
dioxide emissions reduction policy could reduce demand, thereby mitigating costs. However, consumer value would also be affected. Moreover, $\mathrm{CO}_{2}$ emissions in other sectors might increase as consumers shift to direct use of fossil fuels.

* Modeling assumptions regarding the existing AEP system are based primarily on the company's submissions for acid rain studies conducted several years ago and their 1991 Integrated Resources Plan filings to the Public Utility Commission of Ohio. Changes in plans, such as in scheduled capacity retirement or addition dates, could affect the study results. (See Appendix C.) 


\section{Appendix B \\ MAJOR STUDY ASSUMPTIONS}

Appendix B reviews assumptions and estimates used in the study. The outcomes of the modeling effort are highly dependent on these assumptions, calculations, and estimates. All were reviewed and approved by the Global Warming Policy Technical Advisory Group.

\section{SUPPLY TECHNOLOGIES :}

\section{Base Case:}

The performance and cost of fossil-fueled supply-side technologies was based on work by the Electric Power Research Institute (EPRI). Renewable technology characteristics reflect information prepared by the National Renewable Energy Laboratory. Nuclear plants were also based on the EPRI work.

\section{Policy Cases:}

Advanced fossil fuel technologies were available in the Policy Cases. They were characterized based on EPRI and technical background material prepared for the National Energy Strategy by the U.S. Department of Energy. Policy Cases include new nuclear technologies with projected higher capacity factors -- 70 percent vs. 80 percent -- and capital costs of $\$ 1,800$ per $\mathrm{kWh}$. This higher capacity figure is based on information developed by EPRI on the next generation of nuclear technology. The average capacity factor for all U.S. nuclear generation units was 63.1 percent as of May $1991 .{ }^{4}$ Under two Policy Cases, no new nuclear powered generating capacity was allowed. Existing AEP nuclear facilities were not affected.

- Wind energy potential in the AEP region, according to data from the National Renewable Energy Laboratory, was estimated at 3,700 MW of installed capacity in Virginia and $780 \mathrm{MW}$ in West Virginia. However, economic and other barriers would limit development. The availability of wind powered generation was, therefore, capped at 1,500 MW. The cap did not constrain results in the Policy Cases. 
As much as twelve million tons of woody biomass from waste wood, based on data from the Tennessee Valley Authority's Southeastern Regional Biomass Energy Program, were estimated to be available annually in AEP's service territory. This biomass resource could potentially support an estimated 1,576 MW in wood-to-energy power plant capacity. However, this is a maximum technical potential. The availability of biomass was limited to $1,500 \mathrm{MW}$ in the Policy Cases. This condition did not constrain, however, as the cost was higher than other supply, demand, or offset options.

\section{DEMAND-SIDE TECHNOLOGIES:}

\section{Base Case:}

By adopting AEP's load projections, any DSM savings included in the company's estimates were included in the Base Case. Energy conservation resulting from federal appliance standards is assumed to be in AEP's baseline forecast. However, the study's Base Case was modified to include all DSM measures estimated by the project to be available at less than two cents per kWh. By including DSM measures with costs under the AEP avoided cost of providing power, the allocation of the emissions reductions and costs attributed to these measures to the Base Case increases the estimated costs of complying with the $\mathrm{CO}_{2}$ limit. ${ }^{5}$

\section{Policy Cases:}

A supply curve for DSM measures in the AEP region was developed by the Energy Policy Group of Lawrence Berkeley Laboratory and other project consultants.

- An analysis produced by Lawrence Berkeley Laboratory developed supply curves for conserved energy to assess conservation potential in the residential sector. The technical potential for residential sector energy savings was 30 percent in 2005 and 39 percent in 2015. This analysis assumed "frozen efficiency". As such, equipment and buildings in existence as of 1990 are not retrofitted at any point through 2015 and are assumed to remain at constant efficiency. New and replacement equipment and buildings carry the efficiency level of new devices available in 1990. Finally, based on a survey of utility DSM programs across the country, achievable potential was set at 50 percent of the technical potential estimates.

AEP's recently-released Acid Rain Compliance Plan suggests the company is planning to undertake only a minimal conservation effort. 
- Achievable energy conservation potential in the industrial sector is based on an assumed fifty-fifty cost sharing between the utility and industrial consumers and a two to three year payback period. To reflect program costs, the cost of conserved energy was increased by thitty percent for industrial sector DSM.

Achievable savings in the commercial sector were based on incentives of two cents and seven cents per $\mathrm{kWh}$. A requirement of a two-year payback period was assumed. In this sector, the achievable potential assumes that over twenty-five years an aggressive program could capture seventy percent of the technical potential.

\section{OFFSETS - Forestry:}

\section{Base Case:}

No provision.

\section{Policy Case:}

Tree planting and improved forest management can increase the capture and sequestration of carbon/carbon dioxide, thereby cutting net $\mathrm{CO}_{2}$ emissions. The potential for forest offsets in the AEP region are based on data from the U.S. Forest Service completed in December $1990 .^{6}$ This report used detailed data on actual planting practices, acreage of marginal agricultural lands, average merchantable timber yields, historic land rental rates, and the ratio of total ecosystem carbon to timber carbon to estimate the incremental amount of carbon which could be sequestered by a rural tree planting and forest management program in the U.S.

- Only economically marginal and highly erodible cropland and pasture land, and forest lands held by private owners other than the forest industry are included.

- The study uses a forty-year planning horizon. The effects of eventual timber harvesting on the carbon budget are beyond this time horizon, and are not considered. 
There are 40.8 million acres of suitable land estimated to be available in the AEP region. Accepted as the initial estimate, this "technical potential" was adjusted downward in the two offset scenarios.

In Coalbed Methane/ Constrained Trees, this 40.8 million acres was reduced according to enrollment limit estimates developed by ICF -ranging from 7.5 percent of pasture to 40 percent of forest lands. Next, the available acres were reduced (prorated) to reflect AEP's share within the overall region. Finally, two tons of offsets were required for each one ton of offset credits earned (2:1 ratio) to account for losses that could be expected due to weather, pest, and fire.

A Coalbed Methane/ Aggressive Trees case was also tested. This case also began with 40.8 million acres and was reduced to reflect AEP's share of electric generation within the multistate region. Finally, offset availability was further reduced by one-half, to reflect enrollments below the total potential, losses from planting, weather, fire, pests and other factors.

\section{OFFSETS -- Coalbed Methane Recovery:}

\section{Base Case:}

No provision.

\section{Policy Case:}

- The recovery and use of methane gas released from coal mining would reduce emissions of a powerful greenhouse gas. Traditionally, the gas has been dispersed through the ventilation system and discharged to the air. However, technologies exist to capture much of the methane. Some coal companies already collect methane for use on-site as a fuel. Some of the recovered coalbed methane may also be sold to pipelines.

The estimate for the cost-effective potential for coalbed methane recovery was based on seven key assumptions: ${ }^{7}$

- estimates are based on average figures for mines in the region, not mines specifically owned by the company. The AEP total reflects their share of the region's coal use. It is assumed that coal buyers would compete for methane

7 Center for Clean Air Policy, Healing the Environment Part Two: A Look at Coalbed Methane as a Cost-Effective Means of Addressing Global Climate Change. 
offsets. Therefore the estimate is based on AEP's share of coal use.

- the offset ratio for coalbed methane to $\mathrm{CO}_{2}$ is set at $21: 1$ for methane recovered and either used on site or sold to a pipeline. Studies by U.S. E.P.A. and others have used varying ratios (from 11:1 to 21:1) for methane. Conversion ratios differ due to variations in the treatment of the direct and indirect impact of methane.

- only the equivalent of methane resources recoverable from coal produced to meet AEP's use was used.

- only methane resulting from underground mining was deemed feasibly recoverable.

- only one-half of the methane resulting from underground coal mining was considered likely to be of pipeline quality and cost-effective to recover.

- only sixty percent of the methane from mines producing pipeline quality gas was considered economically recoverable.

- AEP's cost for the coalbed methane offsets was set at zero, as recovery is already cost-effective for mine operators and it is assumed that these credits might be included as part of coal sales terms in order to maintain sales.

Approximately 6.4 billion cubic feet (bcf) of coalbed methane offsets would be available to AEP. That is about $2,800,000$ tons of $\mathrm{CO}_{2}$-equivalent offsets. The quantity of coalbed methane recovery offsets available to AEP in both offset scenarios remains unchanged.

\section{CARBON DIOXIDE SCRUBBERS:}

Base Case:

No provision.

\section{Policy Case:}

The method for scrubbing $\mathrm{CO}_{2}$ used in this model is a $\mathrm{CO}_{2} / \mathrm{O}_{2}$ process under development at Argonne National Laboratory. Conventional boiler systems burn fuel/air mixtures. This process involves combustion in an $\mathrm{O}_{2}$-rich environment and incorporates a $\mathrm{CO}_{2}$ recycling loop to provide a diluent to maintain combustion temperatures. The system also operates to remove sulfur and nitrogen oxides. This benefit, however was not counted in this study. This technology has been tested at commercial 
scale at Black Hills Power and Light Company's Customer Service Center Boiler Number 2 in Rapid City, South Dakota. ${ }^{8}$

The availability and cost of disposal for the captured $\mathrm{CO}_{2}$ is critical. The injection of the carbon dioxide in depleted natural gas wells was the only disposal option deemed viable for the AEP region.

The region's geology presents both opportunities and constraints to $\mathrm{CO}_{2}$ injection. The region produces natural gas, but accounts for only 3.4 percent of U.S. annual gas and oil production. However, the region hosts very large underground natural gas storage facilities.

Data on the number of suitable wells that might be available, their capacity, and the feasibility of using them for $\mathrm{CO}_{2}$ disposal is not available. The disposal capacity for underground injection was estimated using cumulative and annual natural gas withdrawals. Cumulative gas withdrawals over the life of fields in Ohio and West Virginia totaled 13,300 bcf. As AEP would compete with other utilities for disposal space, the fraction of each state covered by AEP (one-half) was assumed to equal the fraction of capacity available to the company. Disposal capacity estimates were further reduced by one-half. The AEP share of disposal capacity available from cumulative gas withdrawals was 3,325 bct.

Current and future gas withdrawals free additional disposal space each year. In Ohio and West Virginia, gas production in recent years has totaled 376.3 bcf. Adjusting for AEP's one-half share and by another one-half to reflect the fraction of space that may be useable, an additional 95 bcf per year are available for disposal.

Transport to disposal sites involves converting $\mathrm{CO}_{2}$ to a liquid and pumping it through pipelines. Estimated costs for pipeline transport is $8.56 \mathrm{mills} / \mathrm{kWh}$ for compression and liquification. Another $3.64 \mathrm{mills} / \mathrm{kWh}$ is needed for piping and injection. These estimates were adopted from a report published by Brookhaven National Laboratory

Two 1,300 MW units at AEP's Gavin facility were selected as the most cost-effective choice from among AEP's plants for $\mathrm{CO}_{2}$ scrubbing and disposal. These two units would produce over $310 \mathrm{bcf}$ of $\mathrm{CO}_{2}$ annually. The available injection capacity was sufficient for these two units through 2015. 


\section{NATURAL GAS PRICES:}

\section{Base Case:}

- In the Base Case, natural gas prices were estimated to be $\$ 3.36 / \mathrm{mmBtu}$ in 2005 and $\$ 4.80 / \mathrm{mmBtu}$ in 2015. (1989\$ Delivered Price)

\section{Policy Case:}

- Gas prices are higher in the Policy Cases because increased demand for gas prompted by a $\mathrm{CO}_{2}$ reduction requirement would put upward pressure on gas prices.

The Policy Cases used estimates of $\$ 4.32$ in 2005 and $\$ 5.76$ in 2015. (1989\$ Delivered Price) ICF presented the technical group with a range of estimates from various sources. (See chart below.) Policy Case levels represent mid-range estimates and were adopted by consensus for use in the modeling effort.

GAS PRICE FORECASTS

(\$1990/mmbtu Delivered)

\begin{tabular}{|r|r|r|r|r|r|}
\hline & \multicolumn{5}{|c|}{} \\
\hline 2000 & 3.49 & 3.76 & 4.56 & 3.76 & 5.50 \\
\hline 2005 & 4.47 & & 5.58 & 4.89 & \\
\hline 2010 & 5.68 & 5.93 & 5.60 & 6.18 & \\
\hline $2015+$ & & & 5.41 & & \\
\hline
\end{tabular}




\section{Appendix C}

\section{BACKGROUND ON THE AEP SYSTEM}

The following section describes a number of the most important characteristics of the AEP system.

AEP is one of the largest investor-owned utilities in the country, with eight operating companies in Ohio, West Virginia, Virginia, Indiana, Kentucky, Tennessee, and Michigan. AEP's power generation totaled 188,557 Gwh in 1989. Between 1990 and 2011 total energy use is projected by the company to increase from $105,682 \mathrm{Gwh}$ to $136,523 \mathrm{Gwh}--$ a 1.1 percent annual growth rate.

- AEP is extremely coal-dependent -- with about 87percent of its current generation derived from coal-fired units. Due to its dependence on coal, the company also has disproportionately large $\mathrm{CO}_{2}$ emissions, totaling $106,000,000$ tons of $\mathrm{CO}_{2}$ in 1989 (including emissions associated with wholesale sales). This was about 5 percent of total U.S. $\mathrm{CO}_{2}$ emissions from electric generation, or 1.5 percent of total U.S. $\mathrm{CO}_{2}$ emissions.

- In recent years, AEP's generating capacity has exceeded demand. As a result, off-system sales (wholesale sales to other utilities) are important to the company. In 1990, they accounted for just under 30 percent of total energy use. The $\mathrm{CO}_{2}$ emissions associated with the power generated for wholesale sales is included in the emissions limits established for AEP.

- Electricity prices are comparatively low in the AEP system. In 1990, AEP customers paid an average of 4.27 cents $/ \mathrm{kWh}$, compared to 8.07 cents per $\mathrm{kWh}$ for all investor-owned utilities. Low prices would tend to encourage higher consumption of electricity.

- The Base Case assumes compliance with Acid Rain requirements.

- Because AEP's supply capacity exceeds power demand, the modeling of the $\mathrm{CO}_{2}$ scrubber alternative did not include a capacity penalty (to replace power generating capacity "lost" through the derating associated with this type of technology).

- Neither large facility retirements nor new capacity additions are scheduled before 2000. As of 1990, AEP planned to add $400 \mathrm{MW}$ of coal capacity in 2005 and 1,300 of gas-fired capacity after 2007 (predominantly combined cycle units). AEP's most recent filings on the Acid Rain Compliance Plan called for much larger capacity additions. ${ }^{9}$

9

AEP's filing to the Public Utility Commission of Ohio called for the addition of eighteen combustion turbines (total capacity $2,970 \mathrm{MW}$ ), one pumped storage facility (750 MW), one PFBC ( 340 $\mathrm{MW}$ ), one larger PFBC (680 MW), and two $900 \mathrm{MW}$ coal units (1,800 MW). These combine for a total of $6,540 \mathrm{MW}$. 


\section{Appendix D \\ FOREST OFFSETS ALTERNATIVES}

The Earth's carbon cycle moves around 400 billion tons of carbon each year ( 1.5 trillion tons $\mathrm{CO}_{2}$ equivalent). Roughly 210 billion tons of carbon (770 million tons $\mathrm{CO}_{2}$ equivalent) annually cycle between the atmosphere and terrestrial biota. ${ }^{10}$ Since that is large compared to the roughly 26 billions tons of carbon generated annually by human activities, the potential role biotic systems might play in reducing the threat of global warming is the subject of ongoing consideration.

Terrestrial biota, such as trees, plants, grasses, and soils, directly affect the $\mathrm{CO}_{2}$ concentrations in the atmosphere. A number of reports have concluded that forestry and land-use practices can increase $\mathrm{CO}_{2}$ sequestration and can help reduce the threat of global warming. ${ }^{11}$ Options include: ${ }^{12}$

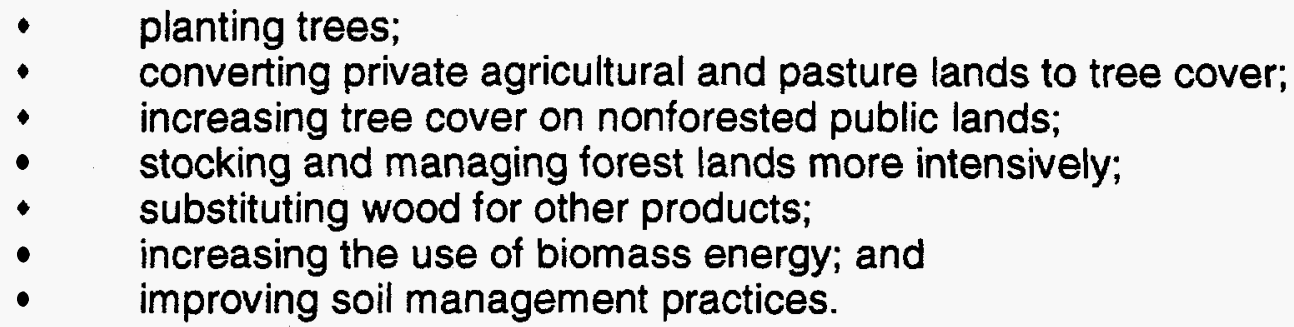

In December 1990, the U.S. Forest Service (USFS) released a report on the cost-effectiveness and availability of forest offsets. ${ }^{13}$ Their report provides estimates for carbon sequestration rates, land rental costs, and treatment costs for fourteen different combinations of land types and forest treatments for each of ten U.S. regions.

There are five key assumptions reflected in the USFS estimates: ${ }^{14}$

1. Only economically marginal and environmentally sensitive cropland and pasture lands, and forest lands held by private owners other than the forest industry are included. These lands have high soil erosion rates and may be ill suited for a wide range of other uses. As such, it is likely that significant environmental benefits might be expected from placing these lands into forest use. These benefits, however, are not considered in the modeling work.

2. Public lands are not included. While this excludes an extensive forestry resource, public forest lands usually require reforestation

\footnotetext{
10 World Resources Institute.

11 National Academy of Sciences; World Resources Institute; Office of Technology Assessment.

12 World Resources Institute.

13 Moulton and Richards.

14 Moulton and Richards.
} 
upon havest. Therefore, they may not yield net reductions in $\mathrm{CO}_{2}$ emissions.

3. Annual land rental rates are 12 perecent to 25 percent higher than historic rates paid under the Conservation Reserve Program (CRP). CRP rates, in turn, are higher than private market rental rates.

4. The study uses a forty-year planning horizon and does not consider the effects of timber harvesting on the carbon budgets of forest ecosystems.

5. The analysis does not consider the startup period for such a program. The assumption has been one of 'instant trees'. A large scale program, of course, would take time to increase greatly the number of trees planted. There would also be an initial growing period when carbon sequestration rates would likely be lower. However, the estimates were based on historic performance of each region. As the USFS authors suggest, improved genetic strains, changes in the species mix, and management for optimizing $\mathrm{CO}_{2}$ uptake, would considerable increase rates of carbon sequestration.

The AEP modeling effort included two alternative scenarios. The first, Constrained Offsets, is the more conservative. However, significant offsets are possible in this case. Up to 10 million tons of $\mathrm{CO}_{2}$ offsets are available by 2015. Aggressive Offsets is less constrained, with up to 46.5 million tons of $\mathrm{CO}_{2}$ offsets available. While this total is almost five times greater than total offsets possible under the Offsets case, it is well below the quantity of forest offsets considered available in the region under the USFS estimates.

The key factors effecting the cost and availability of forest offsets are:

- the availability of suitable land;

- carbon sequestration rates;

- land rental costs; and

- the cost of treatment practices.

\section{AVAILABILITY OF SUITABLE LAND:}

Both the Constrained Offsets and Aggressive Offsets cases begin with the 40.8 million acres of suitable land described by the USFS for the five state AEP region. (See Table 1.)

Under the Constrained Offsets case, however, enrollment assumptions developed by ICF for use in a U.S. E.P.A. report were applied. In these cases, enrollment limits of 7.5 percent for croplands, 30 percent for pasture, and 40 percent for forests were 
imposed. This limited availability to 7.8 million acres, and disproportionately decreased the availability of some of the most productive acres.

A second assumption was that AEP could only access lands within its service territory. As the system's service territory covers only a portion of these states, available acres are cut to 2.2 million acres in the Constrained Offset case.

Under Aggressive Offsets, the 40.8 million available acres is also prorated to reflect the share of acres within AEP's service territory. (Step B) The resulting 11.2 million acres is further reduced by one-half. This adjustment reflects the project's conclusions about realistic enrollment rates, likely losses due to pests or fire, and other factors. Because it seems unlikely that a final Global Warming program would provide credits for passive management, these acres were excluded. As such, 5.3 million acres remain available under Aggressive Offsets.

TABLE 1

POTENTIAL FORESTRY OFFSETS IN THE AEP REGION

\begin{tabular}{|l|l|}
\hline CONSTRAINED OFFSETS & AGGRESSIVE OFFSETS \\
\hline $\begin{array}{l}\text { Step 1: } 40.8 \mathrm{~m} \text { "suitable" acres in } \\
\text { five states. }\end{array}$ & $\begin{array}{l}\text { Step A: } 40.8 \mathrm{~m} \text { "suitable" acres in } \\
\text { five states. }\end{array}$ \\
\hline $\begin{array}{l}\text { Step 2: Enrollment Limits -- 7.5\% } \\
\text { croplands, 30\% pasture, and 40\% } \\
\text { forest = 7.8 m acres. }\end{array}$ & See Step C) \\
\hline $\begin{array}{l}\text { Step 3: Prorate for AEP portion. } \\
\text { 28\%= 2.2 m acres }\end{array}$ & $\begin{array}{l}\text { Step B: Prorate for AEP } 28 \%= \\
11.2 \mathrm{~m} \text { acres }\end{array}$ \\
\hline & $\begin{array}{l}\text { Step C: Reduce } 50 \% \text { to reflect } \\
\text { enrollment, losses, etc. } 5.3 \mathrm{~m} \\
\text { acres }\end{array}$ \\
\hline Step 4: Offset Ratio 2:1 & \\
\hline
\end{tabular}

\section{SEQUESTRATION RATES:}

The USFS sequestration rates vary by land type, treatment, and region. Within the AEP region, they range from 3.3 to 12.7 tons of $\mathrm{CO}_{2}$ /acres/year. Rates are highest for tree planting on the most productive land in the region -- crop lands. However, as illustrated in Table 3, because they are valuable in other uses they carry the highest rental rates. Pasture lands provide a second tier, ranging from 7.6 to 9.1 tons of $\mathrm{CO}_{2}$ /acres/year. Finally, the region's forest lands have the lowest rates, ranging from 3.3 to 8.4 tons of 
$\mathrm{CO}_{2} /$ acres/year. While these areas offer much lower sequestration rates, forest acres have much lower rental rates. The detailed sequestration rates applied in this study are reviewed below in Table 2.

TABLE 2

SEQUESTRATION RATES BY REGION, LAND TYPE, AND TREATMENT MEASURE FOR THE AEP REGION

(Tons $\mathrm{CO}_{2}$ per acres)

\begin{tabular}{|l|l|l|r|}
\hline REGION & LAND TYPE & $\begin{array}{l}\text { TREATMENT } \\
\text { MEASURE }\end{array}$ & $\begin{array}{l}\text { SEQUESTRATION } \\
\text { RATE }\end{array}$ \\
\hline Appalachian & Forest & Active Mgt & 3.3 \\
\hline Appalachian & Forest & Planting & 3.67 \\
\hline Corn Belt & Forest & Active Mgt & 4.77 \\
\hline Corn Belt & Pasture & Dry & 7.33 \\
\hline Appalachian & Pasture & Dry & 7.55 \\
\hline Corn Belt & Pasture & Wet & 7.77 \\
\hline Corn Belt & Forest & Planting & 8.43 \\
\hline Appalachian & Pasture & Wet & 9.09 \\
\hline Corn Belt & Crop & Dry & 9.39 \\
\hline Corn Belt & Crop & Wet & 9.97 \\
\hline Appalachian & Crop & Dry & 10.69 \\
\hline Appalachian & Crop & Wet & 12.72 \\
\hline \hline
\end{tabular}

\section{LAND RENTAL RATES:}

Rental rates were considered a most subjective factor, and were therefore the most difficult to estimate in the USFS study. As seen in detail in Table 3 below, the estimates were conservatively made and remain well above the level of payments made in private land rental payments or payments made to land enrolled in the CRP. This reflects the fact that it would likely take significant additional incentives to encourage landowners to make the long-term commitments entailed with tree planting. 
TABLE 3

LAND RENTAL RATES BY REGION, LAND TYPE, AND TREATMENT

\begin{tabular}{|l|l|l|r||}
\hline REGION & LAND TYPE & TREATMENT & RENTAL RATE \\
\hline Corn Belt & Forest & Active Mgt & 8.55 \\
\hline Corn Belt & Forest & Planting & 8.65 \\
\hline Appalachian & Forest & Active Mgt & 9.73 \\
\hline Appalachian & Forest & Planting & 9.73 \\
\hline Corn Belt & Pasture & Dry & 24.72 \\
\hline Corn Belt & Pasture & Wet & 24.72 \\
\hline Appalachian & Pasture & Dry & 27.81 \\
\hline Appalachian & Pasture & Wet & 27.81 \\
\hline Appalachian & Crop & Dry & 61 \\
\hline Appalachian & Crop & Wet & 61 \\
\hline Corn Belt & Crop & Dry & 81 \\
\hline Corn Belt & Crop & Wet & \\
\hline
\end{tabular}

The highest rental rates are required to attract crop lands in the Corn Belt (\$81) and Appalachian $(\$ 61)$ into forestry. The second highest rates, ranging from $\$ 24.72$ to $\$ 27.81$, are associated with Corn Belt and Appalachian pasture lands, respectively. Suitable forest lands have significantly lower rates, in the $\$ 9-\$ 10$ range.

Crop land rental rate data presented in Table 4 illustrate the conservative nature of these projections. The USFS estimate of a $\$ 61$ rental rate for Appalachian crop lands is almost 60 percent greater than payments made through private transactions for similar lands. Overall, the estimates are 15 percent above the payments made to attract CRP enrollments.

TABLE 4

CROP LAND RENTAL RATE DATA

(\$ per acres)

\begin{tabular}{|l|l|l|}
\hline & APPALACHIAN & CORN BELT \\
\hline USFS Estimate & $\$ 61.00$ & $\$ 81.00$ \\
\hline CRP Rate & $\$ 53.03$ & $\$ 70.58$ \\
\hline Private Rental Rate & $\$ 38.60$ & $\$ 69.80$ \\
\hline USFS vs CRP & $+15 \%$ & $+15 \%$ \\
\hline USFS vs Private & $+58 \%$ & $+16 \%$ \\
\hline \hline
\end{tabular}




\section{TREATMENT COSTS:}

Treatment cost estimates are also taken from the USFS study. They range from a high of $\$ 186$ for establishing trees in Corn Belt pasture lands, to a low of $\$ 31.50$ and $\$ 46.90$ for undertaking more active management efforts on forested lands in the Corn Belt and Appalachian region.

TABLE 5

TREATMENT COST BY REGION, LAND TYPE, AND TREATMENT MEASURE

(\$ per acres)

\begin{tabular}{|l|l|l|r||}
\hline REGION & LAND TYPE & TREATMENT & TREATMENT COST \\
\hline Corn Belt & Forest & Active Mgt & $\$ 31.50$ \\
\hline Appalachian & Forest & Active Mgt & $\$ 49.60$ \\
\hline Appalachian & Crop & Dry & $\$ 62.00$ \\
\hline Appalachian & Crop & Wet & $\$ 62.00$ \\
\hline Appalachian & Pasture & Dry & $\$ 89.00$ \\
\hline Appalachian & Pasture & Wet & $\$ 89.00$ \\
\hline Appalachian & Forest & Planting & $\$ 115.90$ \\
\hline Corn Belt & Forest & Planting & $\$ 132.00$ \\
\hline Corn Belt & Crop & Dry & $\$ 133.00$ \\
\hline Corn Belt & Crop & Wet & $\$ 139.00$ \\
\hline Corn Belt & Pasture & Dry & $\$ 186.00$ \\
\hline Corn Belt & Pasture & Wet & $\$ 186.00$ \\
\hline \hline
\end{tabular}

Treatment costs were annualized over a period of forty years. This period was selected by USFS as "a reasonable lifetime for a program of this magnitude". Assuming a ten percent interest rate, the capital recovery factor used was 0.10226 . These cost estimates were multiplied by this figure to yield an annual cost equivalent.

\section{MODELING RESULTS}

A brief review of the conclusions of the USFS study serves as a comparisons for the results of the AEP project. In the report, USFS assessed the likely impacts and costs of a forestry program aimed at cutting U.S. net emissions of $\mathrm{CO}_{2}$. The study concludes that a program sized to reduce net $\mathrm{CO}_{2}$ emissions by 20 percent would involve 138.4 million acres and cost $\$ 4.5$ billion per year. Costs ranged from $\$ 1.18$ to $\$ 11.81$ per ton 
of $\mathrm{CO}_{2}$ sequestered. $\mathrm{CO}_{2}$ sequestration costs in both scenarios included in this research were well within the range of the USFS report.

In the AEP study, forest offsets were selected by the model based on their cost-effectiveness as measured against other options such as demand-side management, $\mathrm{CO}_{2}$ scrubbing and disposal, renewables, and alternative fuels and technologies with lower $\mathrm{CO}_{2}$ emission rates. The results are displayed in Table 6 and discussed below.

TABLE 6

MODEL RESULTS IN $2005 \& 2015$ (Tons $\mathrm{CO}_{2}$ )

\begin{tabular}{|l|r|r|}
\hline & \multicolumn{1}{|c|}{ Year 2005 } & \multicolumn{1}{|c|}{ Year 2015 } \\
\hline Constrained Offsets & 400,000 & $6,500,000$ \\
\hline Aggressive Offsets & $9,000,000$ & $28,200,000$ \\
\hline
\end{tabular}

Under the Constrained Offsets case, as much as 2,373,000 tons of $\mathrm{CO}_{2}$ forestry offsets were available in 2005 and 6,480,000 tons were available in 2015. An average cost of $\$ 7.69$ per ton of $\mathrm{CO}_{2}$ offsets was used for all offsets selected in this case.

TABLE 7

TOTAL FORESTRY OFFSETS AVAILABLE UNDER THE CONSTRAINED OFFSETS CASE

\begin{tabular}{|l|r|r|}
\hline & \multicolumn{1}{|l|}{ Available Offsets $^{\star}$} & $\begin{array}{l}\text { \% of AEP'S 1989 CO } \\
\text { Emissions }\end{array}$ \\
\hline Year 2000 & 695,000 & $0.7 \%$ \\
\hline Year 2005 & $2,373,000$ & $2.2 \%$ \\
\hline Year 2015 & $6,480,000$ & $6.1 \%$ \\
\hline
\end{tabular}

${ }^{*}$ tons of $\mathrm{CO}_{2}$

Under the Aggressive Offsets case, a marginal cost curve for forestry offsets was developed based on the USFS estimates. The lowest cost -- $\$ 2.50$ per ton $\mathrm{CO}_{2}--$ were available from applying active management practices on existing forest lands in the Corn Belt region. Of the potential 46.5 million tons of $\mathrm{CO}_{2}$ offsets available from forestry, one-fifth has a marginal cost of under $\$ 5 /$ ton of $\mathrm{CO}_{2}$, and another one-sixth fell 
below $\$ 6 /$ ton of $\mathrm{CO}_{2}$. Seventy-five percent of the total were available at costs of less than $\$ 10$ per ton $\mathrm{CO}_{2}$. (See Table 8)

TABLE 8

AGGRESSIVE OFFSETS FORESTRY POTENTIAL MARGINAL COST DISTRIBUTION

Under $\$ 5 /$ ton $\mathrm{CO}_{2}--8,810$ Annual Tons $\mathrm{CO}_{2}$-- $19 \%$

Over $\$ 5$ and up to $\$ 6 /$ ton $\mathrm{CO}_{2}--7,825$ Annual Tons $\mathrm{CO}_{2}--17 \%$

Over $\$ 6$ and under 10.00/ton $\mathrm{CO}_{2}--18,343$ Annual Tons $\mathrm{CO}_{2}--39 \%$

$\$ 10.08$-- 11,502 Annual Tons $\mathrm{CO}_{2}--25 \%$

TABLE 9

AGGRESSIVE OFFSETS:

MODEL RESULTS AND COST CURVE

\begin{tabular}{|l|r|r|r||}
\hline & $\begin{array}{l}\text { COST PER TON } \\
\mathrm{CO}_{2}\end{array}$ & $\begin{array}{l}\text { TOTAL POT. } \mathrm{CO}_{2} \\
\text { SEQUESTERED }\end{array}$ & $\begin{array}{l}\text { CUMULATIVE CO } \\
\text { SEQUESTERED }\end{array}$ \\
\hline CB/Forest/ActMgt & $\$ 2.50$ & 559,300 & \\
\hline CB/Forest/Planting & $\$ 2.62$ & $1,058,000$ & $1,617,300$ \\
\hline AP/Pasture/Wet & $\$ 4.06$ & $2,554,300$ & $4,171,600$ \\
\hline AP/Forest/ActMgt & $\$ 4.38$ & 909,200 & $5,080,800$ \\
\hline AP/Pasture/Dry & $\$ 4.88$ & $3,729,700$ & $8,810,500$ \\
\hline AP/Crop/Wet & $\$ 5.29$ & $4,623,700$ & $13,434,200$ \\
\hline CB/Pasture/Wet & $\$ 5.62$ & $1,099,500$ & $14,533,700$ \\
\hline AP/Forest/Planting & $\$ 5.89$ & 973,600 & $15,507,300$ \\
\hline CB/Pasture/Dry & $\$ 5.96$ & $1,128,800$ & $16,636,100$ \\
\hline AP/Crop/Dry & $\$ 6.35$ & $6,349,400$ & $22,985,500$ \\
\hline CB/Crop/Wet & $\$ 9.55$ & $11,993,900$ & $34,979,400$ \\
\hline CB/Crop/Dry & $\$ 10.08$ & $11,502,800$ & $46,482,200$ \\
\hline
\end{tabular}

2005 Offsets

$9 \mathrm{~m}$ Tons $\mathrm{CO}_{2}$

$\$ 37.7 \mathrm{M} /$ year

$1.3 \mathrm{~m}$ acres

6.88 Tons $\mathrm{CO}_{2}$ /acres/year
2015 Offsets

$28.2 \mathrm{~m}$ Tons $\mathrm{CO}_{2}$

$\$ 120.2 \mathrm{~m} /$ year

$3.4 \mathrm{~m}$ acres

8.44 Tons $\mathrm{CO}_{2}$ /acres/year

in tons of $\mathrm{CO}_{2}$.

$\mathrm{CB}=$ Corn Belt Region. $\mathrm{AP}=$ Appalachian Region . 
The availability and estimated costs of forest offsets had significant impacts on the selection of a least-cost method of complying with the $\mathrm{CO}_{2}$ emission limits. However, while extensive forest offsets were selected, about one-quarter of the total available potential was not selected under the Aggressive Offsets scenario for 2015. This is due in part to the low cost of both DSM and coalbed methane credits.

Under the Aggressive Offsets case (Table 9), the 9 million tons of offsets selected in 2005 had costs per ton of $\mathrm{CO}_{2}$ sequestered ranging from $\$ 2.50$ to $\$ 5.29$. The larger goal of 28.2 million tons of $\mathrm{CO}_{2}$ sequestered in 2015 entailed selection of 3.3 million acres of the 5.3 million acres available. The top marginal cost for a ton of $\mathrm{CO}_{2}$ sequestered, however, remained under $\$ 10$. The annual costs for this program were $\$ 37.7$ million per year in 2005 and $\$ 120.2$ million per year in 2015 . The 28.2 million tons of $\mathrm{CO}_{2}$-equivalent forest offsets provide a major portion of the 46 million ton $\mathrm{CO}_{2}$ emission reduction goal for 2015 . The remainder comes from DSM and coalbed methane recovery credits.

AFFECTED LAND AREA: The 3.3 million acres chosen in 2015 under Aggressive Offsets is 8 percent of the total acreage designated as "suitable" in the five state region. With over 113 million acres in the five state AEP region, 3.3 million acres would commit about 3 percent of this total. There are also about 1.8 million acres in the AEP region currently under ten-year CRP contracts. This forestry program would entail about twice the acres as are currently under CRP contract. But, as forestry is an eligible CRP activity, some portion of existing CRP lands would likely be enrolled in the offset program.

IMPACT ON COMPLIANCE COSTS: When compared to a base case with no emissions reductions requirements, both the Constrained Offsets and Aggressive Offsets scenarios entail some significant costs. Under the more conservative offsets case, the incremental costs of compliance would be about $\$ 700$ million per year. The availability of a much larger forest offset under Aggressive Offsets reduces this burden to about $\$ 170$ million per year (about 2 percent of total AEP revenue requirements in 2015).

The most expensive case examined -- neither offsets, new nuclear plants, nor $\mathrm{CO}_{2}$ scrubbers are allowed -- entails annual incremental compliance costs of $\$ 1.6$ million in 2015. With the exception of some inexpensive DSM, the forestry offsets provide the least cost alternative for cutting net $\mathrm{CO}_{2}$ emissions.

CURRENT EXPERIENCE: The forest offset assumptions used are conservative -particularly the limitation of offsets to the AEP service territory. At least one Independent Power Producer in the U.S. has concluded arrangements to offset projected $\mathrm{CO}_{2}$ emissions from a new generating station by purchasing and helping to preserve forest areas in Paraguay. In this case, the company will pay only about one-half the project cost with the remainder paid by the Paraguayan government, The Nature Conservancy, and a local foundation. Project costs are estimated to be about fifteen cents per metric ton of $\mathrm{CO}_{2}$ emissions offset. 


\section{Appendix E CARBON DIOXIDE SCRUBBERS}

The feasibility and cost of capturing $\mathrm{CO}_{2}$ from the flue gases of coal-fired power plants has been under investigation for many years. Much of this work focused on finding an affordable source of $\mathrm{CO}_{2}$ for use in enhanced oil recovery. However, the prospects for greatly increasing the application of these recovery techniques has declined in tandem with the downward trend in world oil prices. Concern about the impact $\mathrm{CO}_{2}$ emissions generated by fossil fuel consumption may have on the greenhouse effect has renewed interest in alternative approaches for $\mathrm{CO}_{2}$ scrubbing.

$\mathrm{CO}_{2}$ scrubbing and disposal options were made available to the model only after work was completed to customize cost estimates and to characterize conditions in the AEP region. The sections below review two alternative technologies for capturing $\mathrm{CO}_{2}$, three methods for $\mathrm{CO}_{2}$ disposal, and the impact these options have on AEP's ability to meet the $\mathrm{CO}_{2}$ reduction targets.

CO, SEqUESTRATON: Two alternative methods for scrubbing $\mathrm{CO}_{2}$ from the flue gases which can be retrofitted to existing utility-sized coal fired units were reviewed. The first is a stripping system which uses an improved solvent (monoethanolomine (MEA)). The second, a $\mathrm{CO}_{2} / \mathrm{O}_{2}$ process, increases the concentration of $\mathrm{CO}_{2}$ in the flue gas by using a $\mathrm{CO}_{2}$-rich mixture instead of air to burn the fuel. This later alternative offered lower costs and was selected for use in the modeling exercise.

MEA: MEA was used to remove $\mathrm{CO}_{2}$ from coal or coke-fired boilers in the U.S. from the 1930 s through the late 1980 s. It uses a reversible chemical absorption process for removing $\mathrm{CO}_{2}$ from flue gases. In this case, the process requires that flue gases first be cooled. Scrubbing is preceeded by passing desulfurized flue gas through a cooling process. After passage through a contact cooler, the flue gas is exposed to the MEA solution. The solvent absorbs carbon dioxide, and the $\mathrm{CO}_{2}$-rich MEA is collected and pumped to a stripper. A reclaiming cycle which heats the solvent yields $\mathrm{CO}_{2}$ and reusable MEA. The ability to recycle the solvent is an important advantage the MEA process offers over existing stripper systems. However, the requirement that flue gas be desulfurized before exposure to MEA is an important limitation. Unless a power plant already has $\mathrm{SO}_{2}$ scrubbing, the economics of the MEA system would be further skewed by the need to build a desulfurization system. Other limitations include a significant decline in plant efficiency, high in-plant energy use to power the scrubbing system, and significant capital costs.

$\mathrm{CO}_{2} / \mathrm{O}_{2}$ : Argonne National Laboratory (ANL) is developing a process which concentrates $\mathrm{CO}_{2}$ and recovers it from flue gases. The effort was initially designed to reduce the cost of $\mathrm{CO}_{2}$ to supply demand for the gas to be used in enhanced oil recovery processes. 
Conventional boiler systems burn fuel/air mixtures. The resulting flue gas has relatively low concentrations of $\mathrm{CO}_{2}$ due to dilution. The ANL process involves combustion with oxygen and incorporates a $\mathrm{CO}_{2}$ recycling loop to provide a diluent that maintains the combustion temperature in order to yield the same heat transfer as would be obtained with normal air mixtures. Use of the $\mathrm{CO}_{2}$ mixture instead of air significantly increases $\mathrm{CO}_{2}$ concentrations in the flue gas. With coal as the fuel, flue gas $\mathrm{CO}_{2}$ concentrations exceed 70 percent -- compared with less than 20 percent when normal air is the oxidant.

Cost-effectiveness of the ANL process is dependent on a series of variables, such as the size of the plant, the cost of capital, the type of fuel used, and the cost of electricity for the operating the oxygen plant. One important advantage of the ANL process is its ability to serve dual purposes as both a $\mathrm{CO}_{2}$ and $\mathrm{SO}_{2}$ scrubber $\left(\mathrm{SO}_{2}\right.$ is a precursor of acid precipitation.) Because this study is focused on global warming, this benefit to the technology was not reflected in the model.

While it has advantages over the MEA alternative, the $\mathrm{CO}_{2} / \mathrm{O}_{2}$ process does entail significant cost. These include construction of an $\mathrm{O}_{2}$ plant to supply oxygen for mixture with the $\mathrm{CO}_{2}$ provided by the recycle loop. The ANL approach results in decreased plant operating efficiency and requires large amounts of electricity to operate the oxygen plant. Considerable capital costs would also be faced.

$\mathrm{CO}_{2}$ DISPOSAL: Unless affordable alternatives for carbon dioxide disposal are identifiable, $\mathrm{CO}_{2}$ scrubbing could not be considered a viable alternative. A series of options which presented some promise for application in the AEP region were developed. These included ocean disposal, enhanced oil production and other uses, and injection into gas wells and other underground formations. Each is discussed below.

Ocean Disposal: Under this option, recovered $\mathrm{CO}_{2}$ is compressed into liquid form, piped to the ocean, and injected to a depth where it forms a pocket and sinks to the ocean floor. While it may be attractive in theory, there are several concerns associated with this approach. The pipeline necessary for use by AEP would extend over a route of approximately 350 miles to the Atlantic coast ${ }^{15}$ and another 100 miles out across the outer continental shelf. Second, there is no guarantee that the $\mathrm{CO}_{2}$ would remain in the ocean. Some articles refer to a maximum period of a thousand years before the ocean recirculates the $\mathrm{CO}_{2}$ to the surface to be released. Others, however, suggest this recirculation would occur in just a couple of decades. At best, this would be a very temporary solution.

15

Measured from the juncture of the Ohio and West Virginia borders near the Gavin Power plant to the closest point on the Atlantic coast line. 
Third, the effects of $\mathrm{CO}_{2}$ disposal on the ocean environment have not been assessed.

Ocean disposal faces significant limitations, including uncertainty about the environmental impacts and the expense which would be entailed in compressing, piping, and injecting waste $\mathrm{CO}_{2}$ deep in the ocean. Because of these uncertainties and high costs, this options was not considered feasible for AEP.

Enhanced Oil Recovery and Other Uses: Enhanced Oil Recovery (EOR), once expected to play a large role in America's energy supply picture, has been hampered by the historically low prices for oil in domestic and international markets. Even if these prices rose dramatically, however, the economic viability of linking $\mathrm{CO}_{2}$ scrubbing to enhanced oil recovery would be determined by site specific factors and proximity. Since AEP does not lie in a major oil producing region, it appeared that increased demand for $\mathrm{CO}_{2}$ for EOR would be unlikely to effect the company.

Secondary use of $\mathrm{CO}_{2}$ as food grade liquid carbon dioxide may present a niche opportunity for smaller operations. The key to their success, however, will lie in their ability to reduce or even eliminate transportation costs by locating close to the right type of industry. In any case, these would be unlikely to involve power-plant-sized systems. Again, while there is limited potential, demand for food grade $\mathrm{CO}_{2}$ could not absorb much of the $\mathrm{CO}_{2}$ emitted by AEP.

Injection in Gas Wells/Underground: Researchers at the University of Utrecht in The Netherlands have examined the possibility of disposing $\mathrm{CO}_{2}$ collected from scrubbers in depleted gas wells. They calculated that, after exhaustion, Dutch gas fields could hold as much as forty times their current annual $\mathrm{CO}_{2}$ production. Such disposal techniques would be costly, however. Their projections suggest that this method would increase the cost of electricity by about 30 percent. Injection in gas wells was viable in The Netherlands in part due to their extensive dependence on natural gas. In this case, wells are depleted at a rate that allows for injection of current and projected rates of $\mathrm{CO}_{2}$ generation without exhausting storage space.

Due to the advantages of the underground injection option, it was selected as the most likely possibility for the AEP study. However, the capacity for and costs of $\mathrm{CO}_{2}$ disposal are very site specific. Conditions in the AEP region are very different from those in The Netherlands. The key factors associated with underground injection/disposal of $\mathrm{CO}_{2}$ were evaluated.

$\mathrm{CO}_{2}$ could be injected directly into depleted natural gas wells or into other similar underground formations that would serve equally well. The 
geology of the AEP region presents both opportunities and constraints to underground injection as a means of $\mathrm{CO}_{2}$ disposal. While there has been and continues to be natural gas production in this six state region, these state account for only 3.35 percent of total U.S. annual gas and oil production.

However, the region is host to some of the largest underground natural gas storage facilities in the world. Many of the reservoirs or fields which contain natural gas are considered "tight" formations by geologists. In this case, the injection rates at any particular well can never be great. Injections to the same formation through multiple wells is regularly employed for natural gas storage, however, and would be possible for $\mathrm{CO}_{2}$ disposal as well.

Unfortunately, data directly indicating the number of suitable depleted wells that might be available, their capacity, and the feasibility of using them for $\mathrm{CO}_{2}$ disposal is not available. Neither state or federal agencies nor other relevant organizations have records in sufficient detail. Without direct information on depleted gas wells or future projections of gas production from those wells, only qualified estimates of $\mathrm{CO}_{2}$ disposal capacity can be made.

For the purposes of this study, the capacity for underground disposal of $\mathrm{CO}_{2}$ was estimated by using data for natural gas withdrawals as a proxy. It was assumed that the amount of natural gas withdrawn from the initiation of production to date yields an equal amount of imbedded disposal capacity. Since disposal capacity is increased by additional withdrawals, the annual increase in disposal capacity is equal to the volume of gas withdrawn each year. Similar assumptions have been used in other studies.

These assumptions may tend to overestimate actual disposal capacity. Various factors would limit the potential use of gas wells as $\mathrm{CO}_{2}$ disposal sites. These include institutional factors, the willingness of the operators to have their wells used for this purpose, difficulties in assembling rights of way for pipelines necessary for transporting $\mathrm{CO}_{2}$ from power plants to well head, and the procedures for acquiring injection permits. There are also physical limitations, such as maintaining the correct pressure and temperature for maximum storage, using fields that will contain the gas, the size of the reservoir, and the tightness of the formation.

Only limited data was available to provide estimates of the $\mathrm{CO}_{2}$ disposal capacity. Cumulative and annual gas withdrawals were used as the proxy. As AEP would be competing with the region's other utilities for $\mathrm{CO}_{2}$ disposal space, assumptions were made to quantify the space which could be considered available for AEP's use. 
The U.S. Department of Energy does report cumulate gas withdrawals by state. ${ }^{16}$ Total cumulative withdrawals over the life of the gas fields in Ohio and West Virginia was 13,300 bcf. $^{17}$ These two states were of primary interest because they are both the location of many of AEP's large coal-fired plants and are more proximate to the formations where natural gas is produced and stored. The fraction of each state covered by the AEP service region was assumed to equal the fraction of capacity that could be accessed by AEP. Since AEP covers about one half of Ohio and West Virginia, the availability of disposal space was reduced by half. To ensure a relatively conservative estimate, disposal capacity was further reduced by one-half. This was intended to reflect the likelihood that not all such space would be useable or useful for geologic or economic reasons. The $\mathrm{CO}_{2}$ disposal capacity in these two states as represented by cumulative gas withdrawals, therefore, was estimated as 6,650 bcf. The AEP share of space was established as 3,325 bcf.

Annual gas withdrawals would free additional space for $\mathrm{CO}_{2}$ disposal. In Ohio and West Virginia, gas withdrawals total 376.3 bcf annually. After adjustment to reflect AEP's one-half share of the resulting reservoir space and the fraction of this total which may be usable, the amount of additional disposal capacity as represented by annual gas withdrawals would increase by about 95 bcf per year. It is further assumed that this withdrawal rate would be maintained over the period covered in this study.

Because of the large size of the region in this case study, a pipe transportation network would be needed. Much of the gas production in the region is located in a region which also hosts many of AEP's power plants. However, it was assumed that there was sufficient distance between plant and injection/disposal site that it would be necessary to convert $\mathrm{CO}_{2}$ to a liquid form, rather than transporting it as a gas. While this conversion decreases the cost for the pipeline, pumping costs are increased.

The estimated costs for pipeline transport of $\mathrm{CO}_{2}$ for disposal are reported in a 1982 study (updated to $\$ 1990$ ). ${ }^{18}$ Compression and liquification of $\mathrm{CO}_{2}$ is estimated to cost 8.56 mills $/ \mathrm{kWh}$. Another 7.27 mills $/ \mathrm{kWh}$ would be entailed in piping and injecting the $\mathrm{CO}_{2}$ for each 100 miles of pipeline. This includes the cost of the piping system. ${ }^{19}$

MODELING $\mathrm{CO}_{2}$ SCRUBBING AND DISPOSAL FOR AEP: Specific power stations operated by AEP subsidiaries were identified in Ohio and West Virginia. They were evaluated to identify the most advantageous conditions for testing whether the model would select the $\mathrm{CO}_{2}$ scrubbing option.

U.S. Department of Energy, Natural Gas Annual Report.

Ibid.

Brookahaven National Laboratory.

Ibid. 
Selection of specific plants was based on a number of factors. First, only those facilities built on or after 1970 were considered, as it was assumed that such a large capital expense would only be incurred where a facility's useful life was not a constraint. Other plants were not considered because of their distance from known storage and gas fields.

Extrapolation of costs is based on estimates reported by Intech Inc. ${ }^{20}$ They are consistent with the results reported by ANL. ${ }^{21}$

TABLE 10

CARBON DIOXIDE COLLECTION, TRANSPORTATION, AND DISPOSAL METHODS COST ESTIMATES

\begin{tabular}{|c|c|c|c|}
\hline & $325 \mathrm{MW}$ & $800 \mathrm{MW}$ & $1300 \mathrm{MW}$ \\
\hline Net Power in MW & 237 & 585.4 & 953.1 \\
\hline Plant Efficiency & $24.9 \%$ & $24.9 \%$ & $24.9 \%$ \\
\hline Capacity Factor & $65 \%$ & $65 \%$ & $65 \%$ \\
\hline Annual Generation & $1,370,641$ & $3,387,218$ & $5,524,075$ \\
\hline $\begin{array}{l}\text { Capital Costs for } \mathrm{CO}_{2} \text { Rem., } \\
\$ / \mathrm{kWh}\end{array}$ & $\$ 265$ & $\$ 265$ & $\$ 265$ \\
\hline Ann. Op Costs, $\$ / k_{W h}^{\star \star}$ & $\$ 45.8$ & $\$ 45.8$ & $\$ 45.8$ \\
\hline $\begin{array}{l}\% \mathrm{CO}_{2} \text { Removed } \\
\mathrm{CO}_{2} \text { Rmvd, ton/yr } \\
\end{array}$ & \begin{tabular}{|l|}
$94.7 \%$ \\
$1,932,752$ \\
\end{tabular} & $\begin{array}{l}94.7 \% \\
4,776,341 \\
\end{array}$ & $\begin{array}{l}94.7 \% \\
7,775,439 \\
\end{array}$ \\
\hline $\begin{array}{l}\text { Ann. Cost of } \mathrm{CO}_{2} \text { Control } \\
\$ / \text { ton Removed } \\
\$ / \text { ton emis. dec. }\end{array}$ & $\$ 21$ & $\begin{array}{l}\$ 21 \\
\$ 28\end{array}$ & $\begin{array}{l}\$ 21 \\
\$ 28\end{array}$ \\
\hline
\end{tabular}

$\left({ }^{\star *}=\right.$ costs for replacement capacity were not included. First, AEP has excess supply capacity. Second, the IPM generates replacement power from the least cost alternatives available for AEP.)

Additional costs (1990\$) incurred for $\mathrm{CO}_{2}$ removal and disposal include: ${ }^{22}$

- compression and liquification -- 8.56 mills $/ \mathrm{kWh}$, and

\footnotetext{
$20 \quad$ Energy Report. Also, Western Energy Update.

21 Brookhaven National Laboratory.

22 Brookhaven National Laboratory.
} 
piping and injecting $\mathrm{CO}_{2}$ to the storage area costs $3.64 \mathrm{mills} / \mathrm{kWh}$ for 50 miles (includes the cost of the piping system).

A $1500 \mathrm{MW}$ coal-fired power plant with a 10,500 heat rate and a 65 percent capacity factor produces 10 million tons of $\mathrm{CO}_{2}$ per year. Estimates of $\mathrm{CO}_{2}$ production have been adjusted for seventy percent capacity factors (base load plants) and for plant size. At a specific pressure and temperature, ten million tons of $\mathrm{CO}_{2}$ would occupy the same volume as a depleted natural gas well with 167 bcf withdrawn. ${ }^{23}$

The total space needed for $\mathrm{CO}_{2}$ disposal from these eight coal-fired units/plants is 945.5 bcf annually. Given the assumptions made, the available disposal capacity would only accommodate the $\mathrm{CO}_{2}$ generated by these plants for less than four and one-half years. Space created by continued gas withdrawal would free additional space, but it would only accommodate about half the $\mathrm{CO}_{2}$ production of a 1,300 $1,500 \mathrm{MW}$ plant each year.

The disposal capacity constraint resulted in an assumption to limit the number of plants where this option could be selected. After reviewing these factors, the scrubbing option was made available only at the two $1300 \mathrm{MW}$ units at the Gavin plant. This ensured the availability of disposal capacity to accommodate a more extended working life for the scrubbed plant, the scrubber, and the transportation and disposal system.

ANALYSIS RESULTS: The cost estimates used in the model are based on the $\mathrm{CO}_{2} / \mathrm{O}_{2}$ system. Ninety-five percent of $\mathrm{CO}_{2}$ is removed from flue gases with this process. The ANL $\mathrm{CO}_{2} / \mathrm{O}_{2}$ scrubber technology has been tested at commercial scale, but is still considered unproven. The disposal method modeled was injection into depleted underground natural gas wells and similar underground formations. This disposal method is also considered unproven. However, the economics of $\mathrm{CO}_{2}$ scrubbing could be dramatically altered if substantial quantities of $\mathrm{CO}_{2}$ were used in tertiary recovery of oil. In this case, a waste product would be converted into a product line that potentially could generate some revenues.

The study included the option of $\mathrm{CO}_{2}$ scrubbing at an existing AEP facility -- two 1,300 MW units at the Gavin station. Based on the assumptions and estimates reviewed above, the costs of $\mathrm{CO}_{2}$ scrubbing were about $\$ 265$ per kW, with $\$ 12$ per MWh for disposal costs. Scrubbing entails large capital investments, reduced plant efficiency, large power needs for operating an $\mathrm{O}_{2}$ plant and the $\mathrm{CO}_{2}$ transportation and disposal system. However, it provided cost savings compared to other available options. $\mathrm{CO}_{2}$ scrubbing reduced AEP's projected annual compliance costs by $\$ 400$ million in 2015.

$\mathrm{CO}_{2}$ disposal through natural gas well/underground injection for a utility such as AEP which relies on coal for 87 percent of its total electrical generation, must be viewed as only a temporary solution. On a national basis, others have estimated that the amount of $\mathrm{CO}_{2}$ exceeds the amount of natural gas removed by such a large amount that depleted gas wells would only be able to accommodate about a decade of captured $\mathrm{CO}_{2}{ }^{24}$

23

lbid.

24 Brookhaven National Laboratory. 


\section{Appendix F}

\section{DATA SOURCES}

The data used in this study comes from several sources:

- The existing power plant data base is virtually identical to the AEP data base used in the earlier acid rain studies. These data came largely from AEP submissions.

- The Center, with assistance from the Energy Policy Analysis Group at Lawrence Berkeley Laboratories and other contractors, developed demand-side assumptions for all cases.

- Supply-side options were developed by the Center, with review and advice from the Technical Advisory Group. Sources include EPRI, the National Energy Strategy: Technical Annex II, and information provided by other contractors. Conventional fossil-fueled supply options were based upon the work of the Electric Power Research Institute.

- Several advanced supply-side options were included in the Policy Cases. Cost and performance were based on the National Energy Strategy: Technical Annex II.

The cost and performance characteristics of renewable resource options for both the Base and Policy Cases were derived from the Interlaboratory White Paper prepared by the National Renewable Energy Laboratory. 


\section{Appendix G}

\section{NATIONAL DIALOGUE AND TECHNICAL ADVISORY GROUP MEMBERS}

\author{
Arlene Anderson, U.S. DOE \\ Janet Anderson, Northern States Power \\ Dave Baker, IL Dept. of Energy \& Nat. Resources* \\ John Beldock, U.S. DOE \\ Catherine Benham, U.S. EPA \\ Leslie Black, Sen. Comm. on Energy \& Nat. Res. \\ B.B. Blevins, CA Energy Commission \\ Ashley Brown, OH Public Utility Commission \\ Wade Buchanan, CO Office of Policy \& Planning \\ Paul Centolella, $\mathrm{OH}$ Consumers' Council \\ Don Crane, W.R. Grace* \\ Dan Delurey, New England Electric System \\ Bruce Driver, Attorney/Consultant \\ Jerry Duane, U.S. DOE \\ Dan Dudek, Environmental Defense Fund* \\ Alan Edwards, Wyoming* \\ Jerry Eyster, A.T. Massey Coal Co.* \\ Jay Fischer, Brooklyn Union Gas* \\ Ruth Fleischer, House Comm. on Energy \& Env. \\ Ned Ford, OH Sierra Club \\ Dirk Forrister, Office of Rep. Cooper \\ Ken Friedman, U.S. DOE \\ Marianne Ginsburg, German Marshall Fund \\ T.J. Glauthier, World Wildlife Fund \\ Chuck Guinn, NY State Energy Office* \\ Dave Gushee, Congressional Research Service \\ David Hodas, Weidner Univ. School of Law \\ Charles Imbrecht, CA Energy Commission \\ Dick Kerch, Consolidation Coal Company* \\ Jon Koomey, Lawrence Berkeley Laboratory ${ }^{*}$ \\ Florentine Kraus, Lawrence Berkeley Laboratory \\ Dan Lashof, Natural Resources Defense Council \\ Jessica Laverty, Sen. Subcom. on Energy \& Power \\ (" member of Technical Advisory Group)
}

Alice LeBlanc, Environmental Defense Fund ${ }^{\star}$ Mark Levine, Lawrence Berkeley Laboratories*

Bill Libro, Northern States Power*

Kevin Lynch, PacifCorp*

Jim Mahoney, New England Electric System*

Craig Mathews, Brooklyn Union Gas

Jim McKenzie, World Resources Institute

Alden Meyer, Union of Concerned Scientists

John Millhone, U.S. DOE

Lynn Muchmore, NC Depart. of Natural Resources

Steve Nadel, ACEEE

Michael Nix, WI Electric Power Co.

Richard Ottinger, Pace University School of Law

Lou Peoples, Madison Gas \& Electric

Ruben Plantico, NERCO, Inc.*

Rafe Pomerance, World Resources Institute

Sam Sadler, OR Dept. of Energy

Bob San Martin, U.S. DOE

Ken Schaefer, U.S. DOE*

Bruce Schillo, U.S. EPA*

Ira Shavel, ICF Resources, Inc.*

Mike Shelby, U.S. EPA

Scott Sklar, Solar Energy Industry Association

Blair Swezey, NREL*

Randy Swisher, Am. Wood Energy Association

Don Theiler, WI Dept. of Natural Resources

Dave Thornton, MN Pollution Control Agency

Ram Uppuluri, Jt. Inst. for Energy and Environment

Dale Wilhelm, Tennessee Valley Authority

Jim Williamson, NREL

Jim Wolf, Alliance to Save Energy

Randy Wood, NB Dept. of Environmental Control

Renee Zavoico, Sun Company 


\section{BIBLIOGRAPHY}

Brookhaven National Laboratory, "Possible Storage Sites for Disposal and Environmental Control of Atmospheric Carbon Dioxide", F. L. Horn and M. Steinberg, September 1982. These figures are reported to reflect data compiled for Region 5 as defined by the U.S. Department of Energy for federal regions for storage operations.

Center for Clean Air Policy, R. Nicole Werner, Healing the Environment Part Two: $A$ Look at Coalbed Methane as a Cost-Effective Means of Addressing Global Climate Change, July 1991.

Energy Report, March 11, 1991.

ICF Resources, Incorporated. "Overview of ICF's Integrated Planning Model".

Robert J. Moulton and Kenneth R. Richards, "Costs of Sequestering Carbon Through Tree Planting and Forest Management in the United States", U.S. Department of Agriculture, Forest Service, General Technical Report WO-58, December 1990.

National Academy of Sciences, Policy Implications of Greenhouse Warming, National Academy Press, 1991.

U.S. Congress, Office of Technology Assessment, Changing By Degrees: Steps to Reduce Greenhouse Gases, OTA-0-482, U.S. Government Printing Office, February 1991.

U.S. Department of Energy, Energy Information Agency, Monthly Energy Review for August 1991. Page 85.

U.S. Department of Energy, Energy Information Agency, Natural Gas Annual Report.

Western Energy Update, Issue 91-5, March 15, 1991.

Alan M. Wolsky, Edward J. Daniels, and Bassam J. Jody, "Recovering CO2 from Large- and Medium-Size Stationary Combusters", in Air and Waste Management Association, April 1991, Vol 41, No. 4.

World Resources Institute, Marc C. Trexler, Minding the Carbon Store: Weighing U.S. Forestry Strategies to Slow Global Warming, January 1991. 